\title{
Sedimentological interpretation and stratigraphical position of glacigenic deposits in the Napęków area (Holy Cross Mountains, Poland)
}

\author{
Małgorzata Ludwikowska-Kędzia ${ }^{1 *}$, Halina Pawelec ${ }^{2} \&$ Grzegorz Adamiec $^{3}$ \\ ${ }^{1}$ Jan Kochanowski University, Institute of Geography, ul. Świętokrzyska 15, 25-435 Kielce, Poland \\ ${ }^{2}$ University of Silesia, Faculty of Earth Sciences, ul. Będzińska 60, 41-200 Sosnowiec, Poland \\ ${ }^{3}$ Silesian University of Technology, Institute of Physics - Centre for Science and Education, \\ ul. Konarskiego 22B, 44-100 Gliwice, Poland \\ *corresponding author, e-mail: margludwik@gmail.com
}

\begin{abstract}
The identification of depositional conditions and stratigraphical position of glacigenic deposits in the Napęków area is important for the genetic and stratigraphical interpretation of Quaternary deposits in the central part of the Holy Cross Mountains, as well as for a revision of the course and extent of Middle Polish (Saalian) glaciations. These deposits comprise a series of diamictons which occur between sandy-gravelly deposits. Based on results of macro- and microscopic sedimentological investigations, analysis of heavy mineral composition, roundness and frosting of quartz grains, as well as OSL dating, this complex must have formed during the Odranian Glaciation (Drenthe, Saalian, MIS 6). Sandy-gravelly deposits are of fluvioglacial and melt-out origin. Diamictons represent subglacial traction till. Their facies diversity is a result of variations in time and space, complex processes of deposition and deformation, responsible for their formation at the base of the active ice sheet. This glacigenic depositional complex was transformed by erosion-denudation and aeolian processes in a periglacial environment during the Vistulian (Weichselian, MIS 5d-2).
\end{abstract}

Keywords: lithofacies, microstructures, lithostratigraphy, chronostratigraphy, Pleistocene, Central Poland

\section{Introduction}

Glacigenic deposits in the central part of the Holy Cross Mountains are poorly known as far as environmental conditions and depositional processes as well as stratigraphical position are concerned. Publications on Pleistocene glaciations in this area do not contain explicit descriptions of their course but do provide disputable views on their extent, the resultant relief and deposits, or style of deglaciation (see e.g., Czarnocki, 1927, 1931; Walczowski, 1962, 1968; Lamparski, 1970; Łyczewska, 1971, 1972; Filonowicz, 1972, 1976, 1980; Różycki, 1972a, b; Kosmowska-Sufczyńska, 1972; Radłowska \& Mycielska-Dowgiałło, 1974; Liszkowski, 1976; Mycielska-Dowgiałło, 1978; Lindner, 1978, 1980, 1984, 2004; Kowalski et al., 1979; Kowalski, 1988). Such highly divergent views have resulted in inconsistent genetic and stratigraphical interpretations of glacigenic deposits in this region (e.g., Sołtysik, 1998, 2002; Ludwikowska-Kędzia, 2000; Ludwikowska-Kędzia \& Pawelec, 2011; Ludwikowska-Kędzia et al., 2013). Detailed documentation of conditions and processes underlying Quaternary depositional environments in the central part of the Holy Cross Mountains is further hindered by the fact that the forms of glacial relief are weakly visible, which is usually attributed to the destructive role of erosion and denudation processes operating under periglacial conditions. Moreover, the influence of sub-Quaternary surface relief on the course of glaciations in this region is poorly understood.

In the present paper we report the results of detailed investigations of glacigenic deposits near 

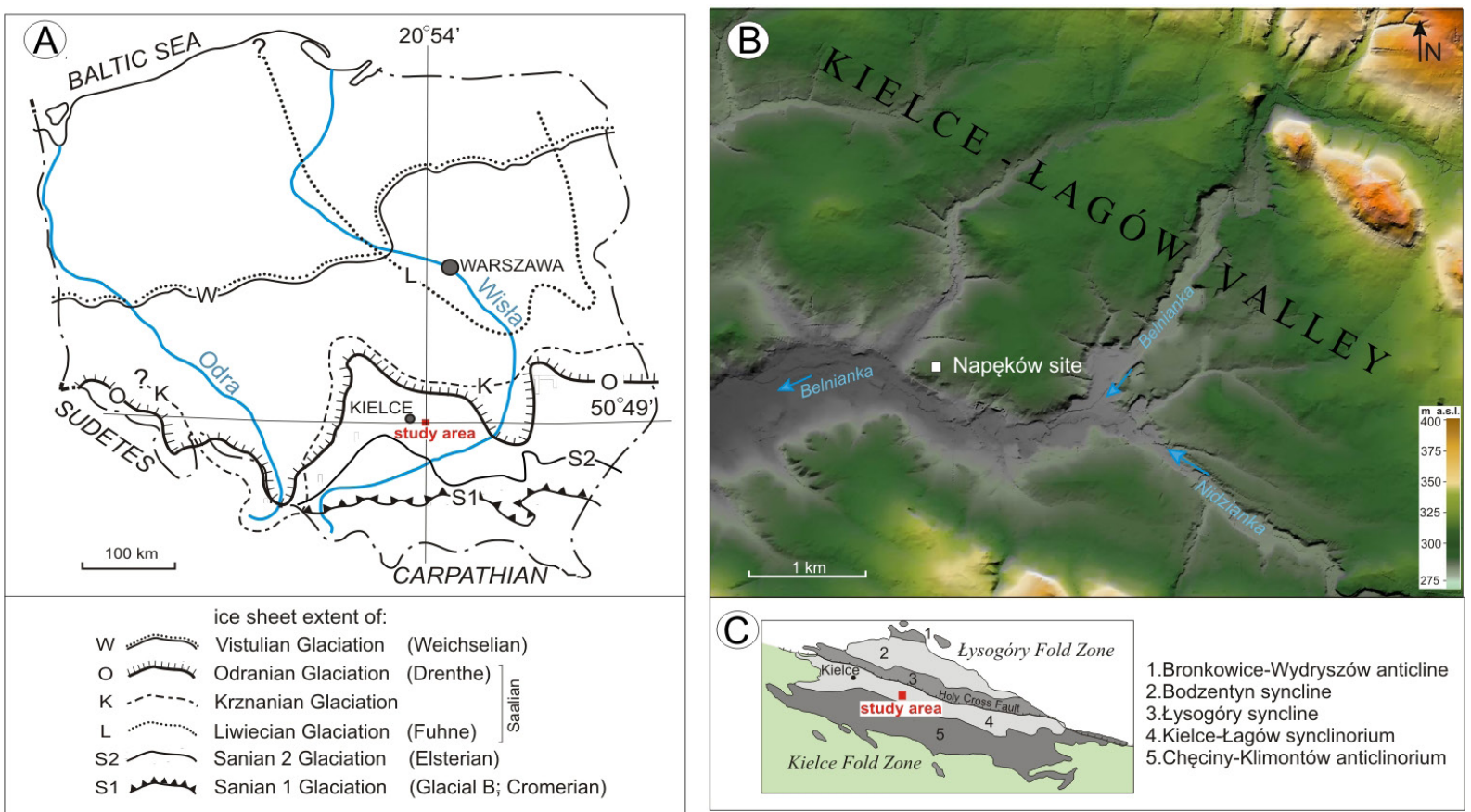

Fig. 1. Location of the study area in relation to: A - extent of Pleistocene ice sheets in Poland (after Marks, 2011; Linder \& Marks, 2012); B - DEM fragment of the Kielce-Łagów Valley; C - tectonic units of the Palaeozoic core of the Holy Cross Mountains (after Czarnocki, 1957; Znosko, 1962; Konon, 2008)

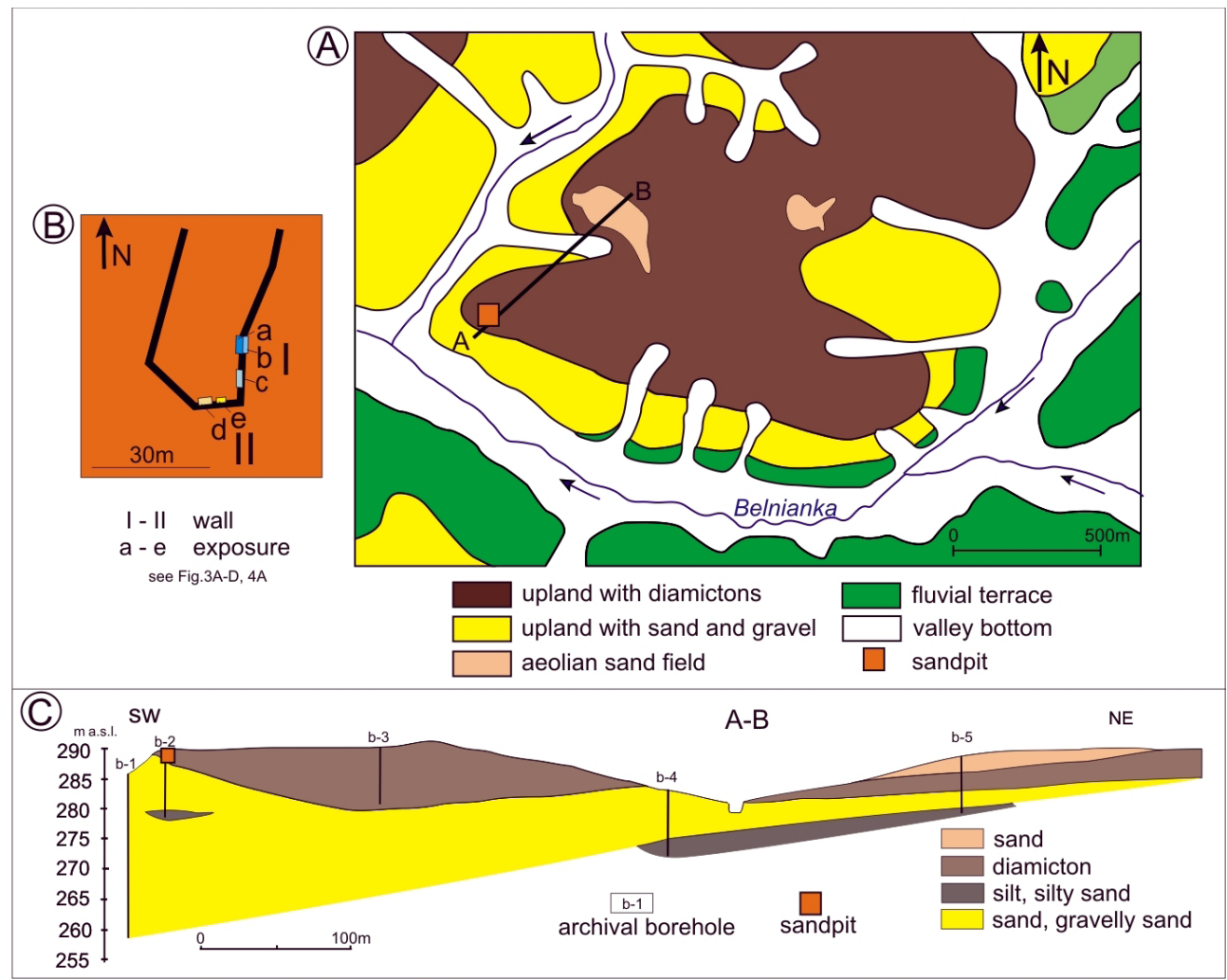

Fig. 2. Geomorphology of the study area: A - geomorphological sketch; B - situational sketch of sandpit with location of exposures Ia-c, IId-e; C - geological cross-section based on archived hydrogeological data and boreholes (Gad \& Juszczyk, 1986) 
the village of Napęków in the Kielce-Łagów Valley (Fig. 1). They are represented by two series of sandy-gravelly deposits separated by two diamicton beds. The purpose of this study is to identify the conditions of deposition and determine the stratigraphical position of these deposits.

\section{Study area}

The outcrop of glacigenic deposits is situated in the central part of the Holy Cross Mountains, in the Kielce-Łagów Valley $\left(50^{\circ} 49^{\prime} \mathrm{N}, 20^{\circ} 54^{\prime} \mathrm{E}\right)$, about $20 \mathrm{~km}$ to southeast of Kielce, near the village of Napęków (Fig. 1A, B), in the Kielce-Łagów synclinorium of the Palaeozoic core of the Holy Cross Mountains (Czarnocki, 1957; Znosko, 1962) and in the Kielce Fold Zone (Konon, 2008) (Fig. 1C). The sub-Quaternary bedrock of the Kielce-Łagów Valley comprises Lower Devonian sandstones, Upper Devonian carbonates (limestones and dolomites) and Lower Carboniferous claystones and siltstones with greywacke interlayers (Filonowicz, 1969, 1976). The valley is surrounded in the north and south by the Łysogóry and Brzechowskie and Orłowińskie Ranges, respectively, which are composed mostly of Cambrian sandstones, quartzites and shales (Filonowicz, 1969, 1976). Mineralogical features of these weathered Palaeozoic (and also Mesozoic and Paleogene-Neogene) rocks in the Holy Cross Mountains, i.e., especially the composition of the group of resistant minerals, were inherited by Quaternary sediments deposited in a range of environments, including a glacial one (Ludwikowska-Kędzia, 2013). This phenomenon is typical of Quaternary deposits in the Kielce-Łagów Valley.

The deposits studied occur within the erosion-denudation spur between the Belnianka River and its right-bank tributary (Fig. 2A). The deposits are 1.5-2.4 m thick, and are exposed along two, near-perpendicular faces in an abandoned sandpit (Fig. 2B). They are represented by diamictons and sandy-gravelly deposits. Diamictons form part of a moraine with strongly denuded surface (Filonowicz, 1976), which reaches 290-295 m a.s.l. (Fig. 2C). These Pleistocene deposits are an example of the "upland facies" (Czarnocki, 1950), as distinguished in the Holy Cross Mountains, which occurs on Palaeozoic bedrock elevations, in contrast with "valley facies", which are found in bedrock depressions.

The age of these deposits is disputable, despite the fact that they are related to the period of South Polish (Cromerian Complex) glaciations (e.g., Filonowicz, 1972, 1976; Kowalski et al., 1979; Lindner, 1984, 2004), i.e., Sanian1(Glacial B, Cromerian,
MIS16) and Sanian2 (Elsterian, MIS12) (Fig.1A) and / or Middle Polish (Saalian) glaciations (Filonowicz, 1980), i.e., Krznanian (Saalian, MIS8) and/or Odranian (Drenthe, Saalian, MIS6).

\section{Methods}

The series studied is exposed in the 15-m-long face I (oriented N-S) and 10-m-long face II (oriented E-W) so that deposits may be observed along two transects. Three sections $(a, b$, and c were investigated in face I, and two (d and e) in II (Fig. 2B).

Field work included: (1) a detailed lithological analysis, (2) measurements of deposit structure, (3) sediment sampling for analyses of textural and micromorphological features. Lithofacies were labelled according to the codes of Miall (1978, 1985), inclusive of subsequent modifications (Zieliński \& Pisarska-Jamroży, 2012) (Table 1).

Three oriented and undisturbed samples of sediment were collected for micromorphological analysis. These samples were taken using Kubiena boxes sized $7 / 10 / 6 \mathrm{~cm}$. All samples were oriented in a vertical and parallel plane to the direction of movement. Next, the samples were impregnated with a polyester resin according to the method described by Brewer (1964), and thin sections were prepared. Thin sections were analysed under an optical microscope (Olympus BX-51) under plane-polarised light so as to identify the texture and structure of skeleton grains of sediment as well as under cross-polarised light in order to identify oriented domains of fine silt and clay (plasmic fabric). The

Table 1. Lithofacies code symbols used in this study

\begin{tabular}{ll}
\hline Code & \multicolumn{1}{c}{ Texture } \\
\hline$B$ & boulder \\
$G$ & gravel \\
$G S$ & sandy gravel \\
$S$ & sand \\
$S G$ & gravelly sand \\
$S D$ & diamictic sand \\
$D S$ & sandy diamicton \\
$D M$ & muddy (clayey) diamicton \\
\hline \multicolumn{2}{c}{ Structure } \\
\hline$m$ & massive \\
$h$ & horizontal stratification \\
\hline$l$ & low-angle (<15) cross-stratification \\
$p$ & planar cross-stratification \\
$d$ & deformed \\
\hline & $\quad$ Diamicton framework \\
\hline$\left(m_{1}\right)$ & matrix-supported, rare clasts $(<15 \%)$ \\
$\left(m_{2}\right)$ & matrix-supported, common clasts $(15-50 \%)$ \\
\hline & $\quad$
\end{tabular}



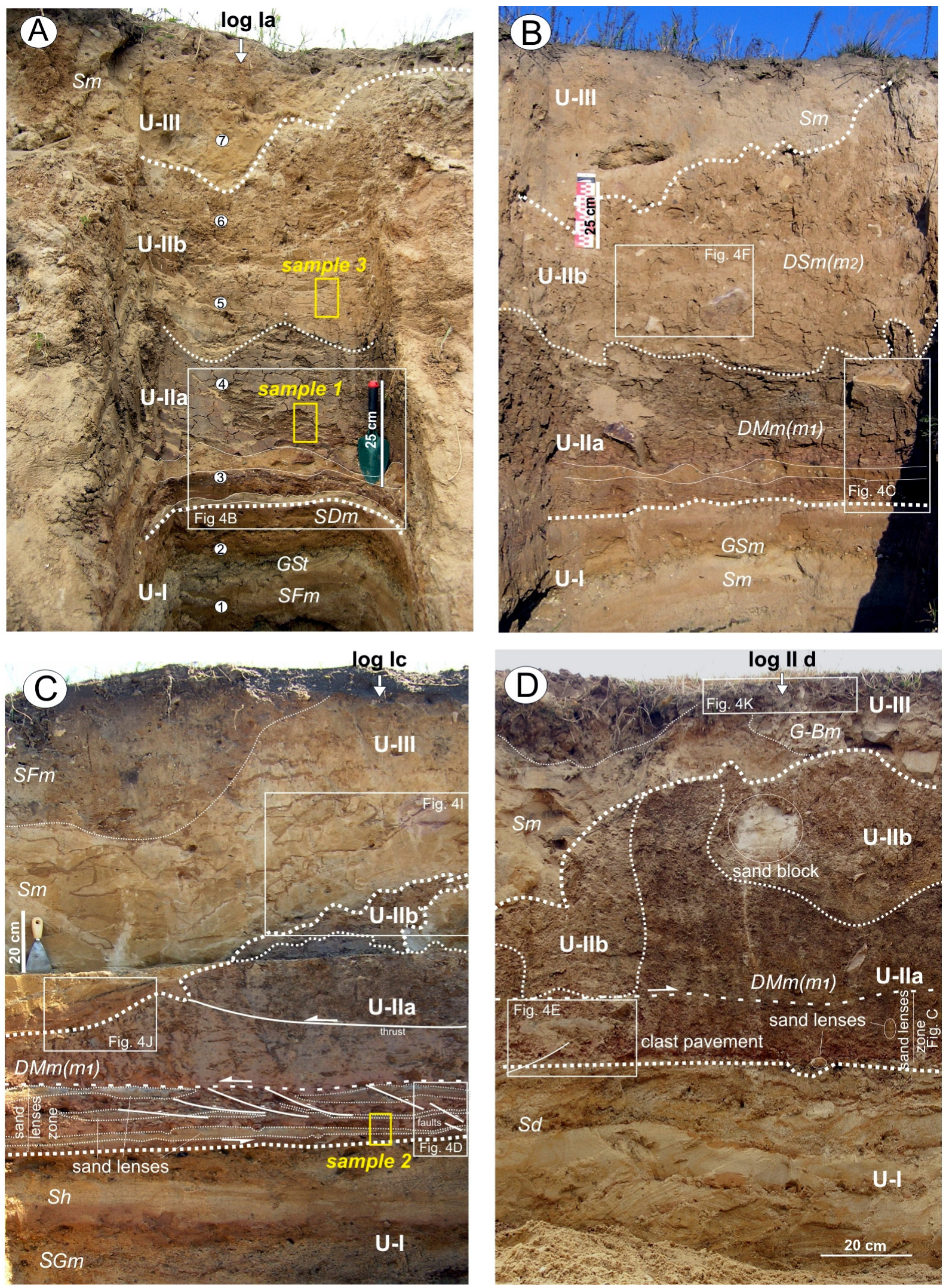

Fig. 3. General view of the glacigenic deposit sequence: $\mathbf{A}$ - face I/exposure a, with location of samples taken for microstructural analyses (sample 1,3); B - face I/exposure b; C - face I/exposure c, with location of sample taken for microstructural analyses (sample 2); D - face II/exposure d 
analysis was conducted at low magnification (ranging from $x 10$ to $x 100)$, which is helpful for structural interpretation. Higher magnifications make it possible to observe individual grains. Samples were described adopting the structural terminology of van der Meer (1993), Menzies (2000) and Carr (2004).

A standard analysis of textural features of deposits according to Mycielska-Dowgiałło (2007) (grain-size distribution, roundness and frosting of quartz grains, and heavy-mineral composition) was carried out. The sand and gravel material was dry sieved using a column of Fritsch sieves with mesh diameter every $0.5 \varphi$. Roundness and frosting of quartz grains were analysed in sand fraction (0.5-0.8 mm) by the Cailleux method (1942), modified by Goździk (1980) and Mycielska-Dowgiałło \& Woronko (1998). The method combines the degree of rounding in the 9-degree scale proposed by Krumbein (1941) and the micromorphology of quartz grains. Mineralogical analyses were done for the $0.1-0.2 \mathrm{~mm}$ fraction. The light and heavy fractions were separated in bromoform (density = $2.89 \mathrm{~g} / \mathrm{cm}^{3}$ ). Heavy minerals were analysed under a Nikon polarising microscope at 100-200x magnification. In each sample at least 300 grains of transparent (non-opaque) minerals were identified. Together with opaque minerals, approximately 600 grains per sample were counted. This work also broadened the interpretation of previously published data on heavy mineral composition of deposits from the Napęków site (Ludwikowska-Kędzia, 2013).

Five samples of sandy deposits were dated by the OSL method in the Luminescence Dating Laboratory at Gliwice.

\section{Description and genetic interpretation of deposits}

Three series of deposits (units I-III) have been distinguished at Napęków (Figs. 3, 4). Sands and sandy gravels (unit I) are visible in the lower part of the exposure. They are overlain by diamicton beds (unit II): lower diamicton with clayey matrix (unit IIa), and upper diamicton with sandy matrix (unit $\mathrm{IIb}$ ). Diamictons are covered by sands with gravel-debris layer (unit III).

\subsection{Unit I. Sands and sandy gravels}

Sands of unit I occur at a depth of $1.25 \mathrm{~m}$, locally $1.70 \mathrm{~m}$ below ground level (the bottom of the series not having been reached) (Figs. 3A-D, 4A). The lower part of unit I consists of sand with planar cross-stratification $S p$ (in places with low-angle cross-stratification $S l$ ), and sand with horizontal stratification Sh (Fig. 4A). The upper part of unit I consists of massive sand $S m$ (locally of diamictic sand SDm) and/or massive sandy gravel GSm(S$G m)$, locally with trough cross-stratification GSt.

The lithofacies $S p(S l)$ and $S h$ are composed mainly of grey and yellow sands, medium- and finegrained, with the content of fines up to $1-4 \%$. These lithofacies are 5-30 cm thick and wedge-shaped (in places, in the bottom part of series - sheet-like). They have distinct, sharp lower and upper boundaries. Scattered clasts of fine gravel are visible in the bottom parts of the layers. The lithofacies $S m$ is also composed of grey and yellow, fine-grained sands, locally with single clasts of fine gravel. The content of fines is up to $1 \%$. This lithofacies is $5-25$ $\mathrm{cm}$ thick, and its upper and lower boundaries are deformed locally by small-scale folding and thrusting (Fig. 3D). Diamictic sand SDm, with scattered gravel clasts, occurs sporadically, in the top part of unit I. It is brown, $10-15 \mathrm{~cm}$ thick and massive (Fig. $3 \mathrm{~A})$. The sandy gravel lithofacies GSm(GSt, SGm) is rust-coloured, 10-15 cm thick, lens-shaped, and, in places, passes horizontally into massive sand beds Sm (Figs. 3, 4A). The upper and lower boundaries of lithofacies GSm(GSt, SGm) are sharp, the upper one is deformed in places. It is a matrix-supported, and, in places, clast-supported deposit, composed mainly of medium-grained gravels (the maximum diameter of clasts being $1.5 \mathrm{~cm}$ ). Gravels of local Palaeozoic and Mesozoic rock predominate. They are accompanied by Scandinavian erratics - granites and gneisses. The matrix consists mostly of coarse- and medium-grained sand as well as finegrained gravel. The content of fines is up to $1 \%$. The deposit is massive, locally with preserved traces of trough cross-stratification GSt. It contains concentrations of iron hydroxides and streaks of manganese compounds.

Deposits of unit I are characterised by a predominance of quartz grains representing aquatic environment, i.e., EM/EL and EL (68-85\%) (Fig. 5A). The content of OTHER grains is relatively high (17$20 \%$ ), while that of grains of aeolian origin (RM and $\mathrm{EM} / \mathrm{RM})$ is extremely low $(0-12 \%)$. Quartz grains occurring in the upper part of unit I are more diverse with respect to their surface character.

Heavy-mineral analysis (Ludwikowska-Kędzia, 2013) indicates that these deposits are characterised by only a slightly higher percentage of transparent minerals $(52-56 \%)$ than that of opaque minerals (44-48\%) (Fig. 5B). Heavy mineral grains are well 

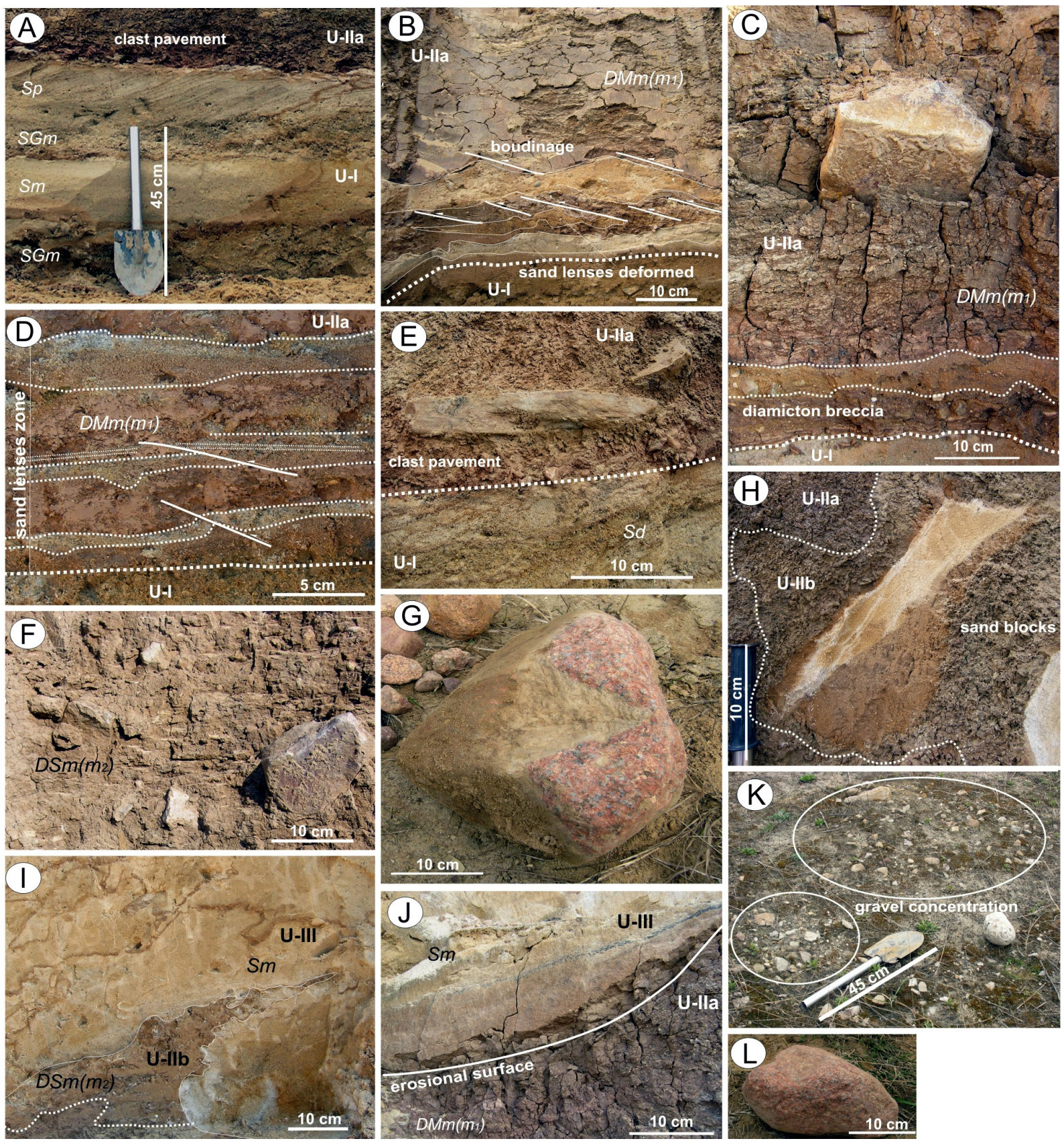

Fig. 4. Glacigenic deposits at Napęków: A - erosional contact between sands (unit I) and diamicton (unit IIa) in exposure IIe (see Fig. 2B); B - bottom of diamicton (unit IIa) with sand lenses and distinct deformations of folding, faulting, small-scale thrusting and boudinage type (see Fig. 3B); C - sandstone clast resembling a dropstone in diamicton (unit IIa), and dimicton breccia/laminated diamictic facies visible at the bottom (see Fig. 3B); D - bottom part of the stratified(?) diamicton (unit IIa), with visibly deformed sand lenses (see Fig. 3C); E - fragment of clast pavement at the bottom of diamicton (unit IIa), with distinct orientation of clasts and shear zones (see Fig. 3D); G - Scandinavian boulders with traces of their former presence in traction zone (smoothed and striated boulder surfaces, wedge striae, stoss-and-lee forms), from diamicton IIb; $\mathbf{H}$ - sand block at contact between two diamictons (units IIa and IIb), with partially preserved internal structure; in face II; I - deformed diapiric form of diamicton (unit IIb), and sands with upper lamellae (unit III) (see Fig. 3C); J - erosional contact between sands (unit III) and diamicton (unit IIa), showing lower lamella with accumulated iron compounds (see Fig. 3C); K - ground surface transformed by aeolian processes (see Fig. 3D); L - Scandinavian boulders; from unit III

sorted, medium and poorly rounded, with traces of traces of oxidation predominate in the group of mechanical destruction. Primary iron oxides with opaque minerals, and constitute $38-40 \%$ of all iden- 


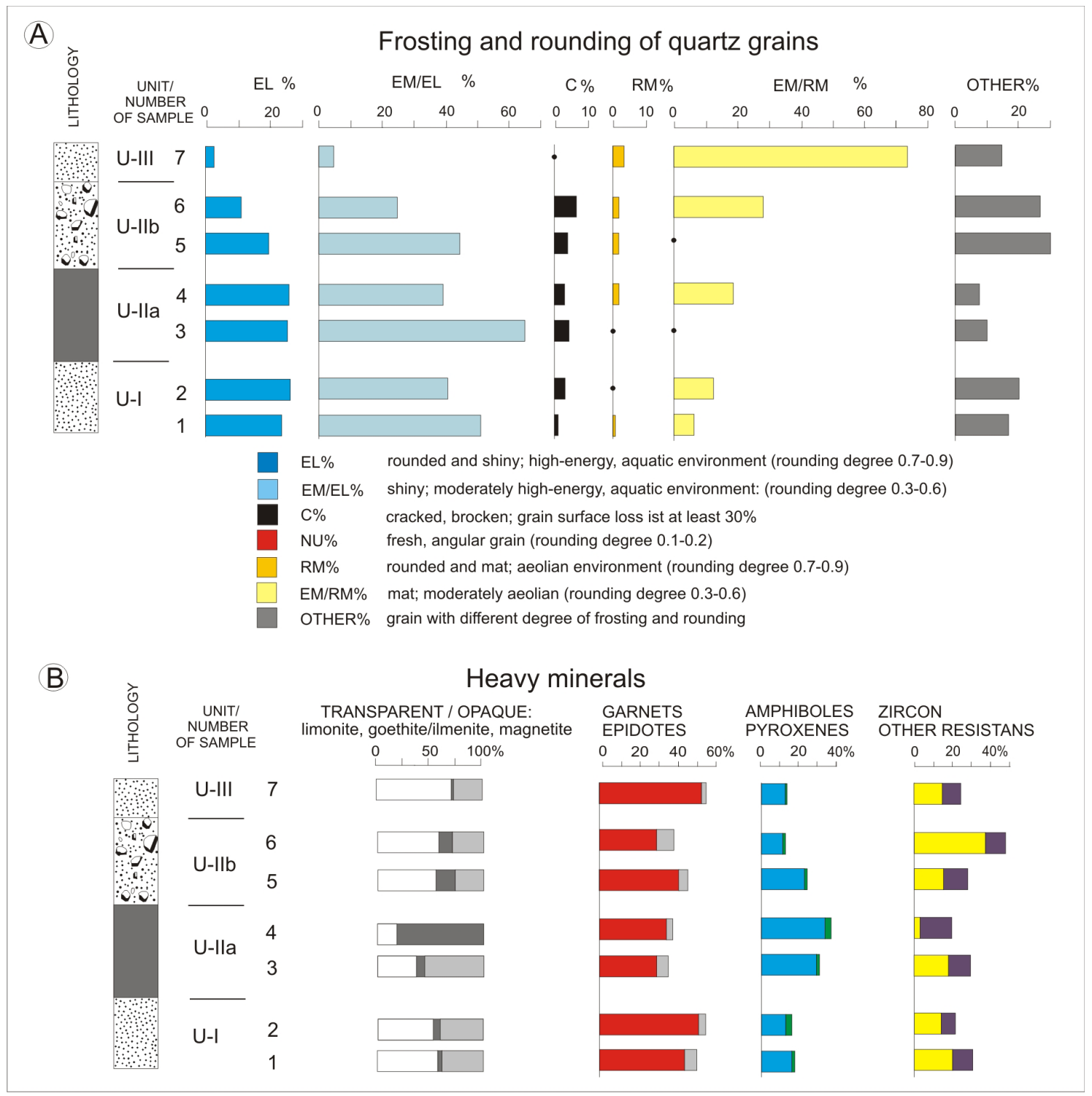

Fig. 5. Sedimentological characteristics of deposits at Napęków: A - roundness and frosting of quartz grains; B heavy-mineral composition

tified heavy minerals. The percentage of secondary iron oxides is low (5-7\%). Semi-resistant minerals - garnets and epidotes (52-56\%) - predominate in the group of transparent minerals (considered $100 \%$ ) (Fig. 5B). The resistant minerals (28-30\%) are represented mainly by zircon, as well as staurolite, tourmaline, and kyanite, while non-resistant minerals (16-18\%) comprise amphiboles and pyroxenes. The main heavy minerals follow the garnets >amphiboles>zircon (staurolite, epidotes) scheme.

\subsubsection{Interpretation}

Lithofacies $S p$ is a record of deposition from hydraulic flow, i.e., from rhythmic bedload transport under conditions of lower flow regime (Zieliński, 1998, 2014). It formed as a result of accre- tion of sandy transverse bars in a braided channel. The co-occurrence of lithofacies $S p$ and the series of wedge-shaped lithofacies with low-angle cross-stratification Sl may illustrate the transition from the lower to upper flow regime. Transverse bars have probably been reshaped in a braided channel that became shallower (cf. Miall, 1980; Zieliński, 1993). The sheet-shaped lithofacies Sh is typical of upper-stage plane-bed conditions, usually laid down under supercritical flow conditions. It may be also a record of very shallow channel flows, which resemble sheet flows, in a channel with temporary variations in water supply (cf. Zieliński, 1993). Alternatively, it may record a short-lived fluctuation of flow - in glacial environments it may be the result of seasonal changes of ablation rate or 
shorter-term changes in discharge relating to rainfall. The lithofacies association $S p(S l), S h$ represents alluvium of sand-bed braided channels (rather shallow or gradually becoming shallower) of proglacial (outwash?) rivers functioning under conditions of greater water supply, e.g. due to seasonal ablation episodes (cf. Pisarska-Jamroży, 2006, 2007). Lithofacies GSm (GSt, SGm) is a record of short, intensive flood flows. This is evidenced by the preserved traces of trough cross-stratification that indicate a stage of dissection of sandy bars by small channels as well as the existence of conditions favouring accumulation of gravel sheets (cf. Miall, 1977; Zieliński, 1993, 2014). The tabular lithofacies $S m$, occurring in the upper part of the series, may be interpreted as having been deposited from suspension - probably from high-density suspension (cf. Pisarska-Jamroży, 2007). Such an interpretation is hinted at by the poor sorting of sands, and the occurrence of fine gravels, which are chaotically distributed throughout. However, deformation of upper and lower parts of this lithofacies indicate that its massive structure may be a secondary feature that formed by obliteration of primary structure, e.g. as a result of deposit liquefaction. The liquefaction process may have been triggered by a mechanical factor (Gradziński et al., 1986), e.g. the deposition of overlying diamictons (unit II). The lithofacies of diamictic sand SDm with scattered gravel clasts occurs sporadically. It may be interpreted as an indicator of decreasing discharge and increasing suspension density.

The horizontal diversity of lithofacies association, found in a small area, indicates that the braided river channel was characterised by spatial diversity of its bottom relief and rapid changes of water level. Sandy transverse bars formed in shallow zones of the channel. They were sporadically washed away during short flood flows. These flows resulted in the deposition of gravel lithofacies. A decrease of discharge is evidenced by diamictic sand deposition. The deformations of sands in the upper part of unit I - small-scale thrusting, folding and shearing - should be related to depositional conditions of the overlying diamictons of unit II.

The fluvioglacial origin of the deposits of unit I is indicated by the wide diversity of surface characters of quartz grains, with a predominance of grains representing fluvial environments (cf. Woronko, 2001, 2012), and the predominant scheme of the main heavy minerals - typical of fluvioglacial sands of the Polish Lowland (cf. Racinowski, 2008, 2010), and found also in the Kielce-Łagów Valley (cf. Ludwikowska-Kędzia, 2013). A high percentage of OTHER grains may indicate post-deposi- tional processes that affected the deposits "in situ" (cf. Woronko, 2012). The predominance of primary iron oxides (ilmenite, magnetite) over secondary ones should not be necessarily interpreted as the result of repeated redeposition of alluvia, and as the indicator of maturity of the detrital material (cf. Barczuk \& Nejbert, 2007). In the Holy Cross Mountains it may be indicative of short transport and accessibility of weathered bedrock (Palaeozoic and/ or Mesozoic) of Holy Cross Mountains.

\subsection{Unit II. Diamictons}

\subsubsection{Unit IIa. Lower diamicton}

The lower diamicton $D M m(m 1)$ overlies the deformed, and erosionally truncated (in places) sands of unit I (Figs. 3A-D, 4A-D). It occurs at a depth between 1.7 and $1.0 \mathrm{~m}$, and its thickness ranges from 50 to $70 \mathrm{~cm}$. Wet diamicton is of cherry colour due to a clayey matrix (Fig. 4D), while dry it is brown. In places, only in the dry state, structure is visible in the form of plastically deformed laminae (light pink and dark cherry) as well as irregular lenses and boudins (Figs. 3B, 4C) Crushed and broken fragments of breccia type occur here and there (Figs. $3 \mathrm{~A}-\mathrm{D}, 4 \mathrm{~B}-\mathrm{C})$. The diamicton is clast-supported in its lower part, composed of well-rounded gravels, mainly coarse and very coarse (up to $4 \mathrm{~cm}$ ). Large, sharp-edged fragments of sandstone occur in places (Figs. 3A-D, 4C). In the lower part of the diamicton these clasts form a clast pavement (Fig. 3D, 4A, E) clearly visible in face II) with distinct clast long-axis orientation (Fig. 4E). The measured azimuths of clast longer axes suggest transport of material from the southeast to the northwest.

In face I of the exposure, in the lower part of the diamicton, a $15-25-\mathrm{cm}$-thick zone containing sand lenses is evident, including the following types: sheet $(5-8 \mathrm{~cm}$ thick), pocket $(8-10 \mathrm{~cm}$ thick) and stringer (1-3 cm thick) (cf. Kessler et al., 2012) (Figs. 3A-C, 4D). The lenses are composed of fineand medium-grained sand, medium sorted, yellow, grey or brown. These sands have massive structure, no primary structures. Most of them are deformed by small-scale folding (asymmetrical folds) or faulting (normal and reverse faults), small-scale thrusting and boudinage (Figs. 3, 4B-D). The zone with sand lenses is not visible in face II of the exposure where the above-described clast pavement is found.

In the upper part of the diamicton the content of gravel fraction is low. Single, sharp-edged fragments of sandstone (up to $30 \mathrm{~cm}$ ) are found. Most of these clasts have vertically oriented long axes but those occurring near the bottom of the diamicton 

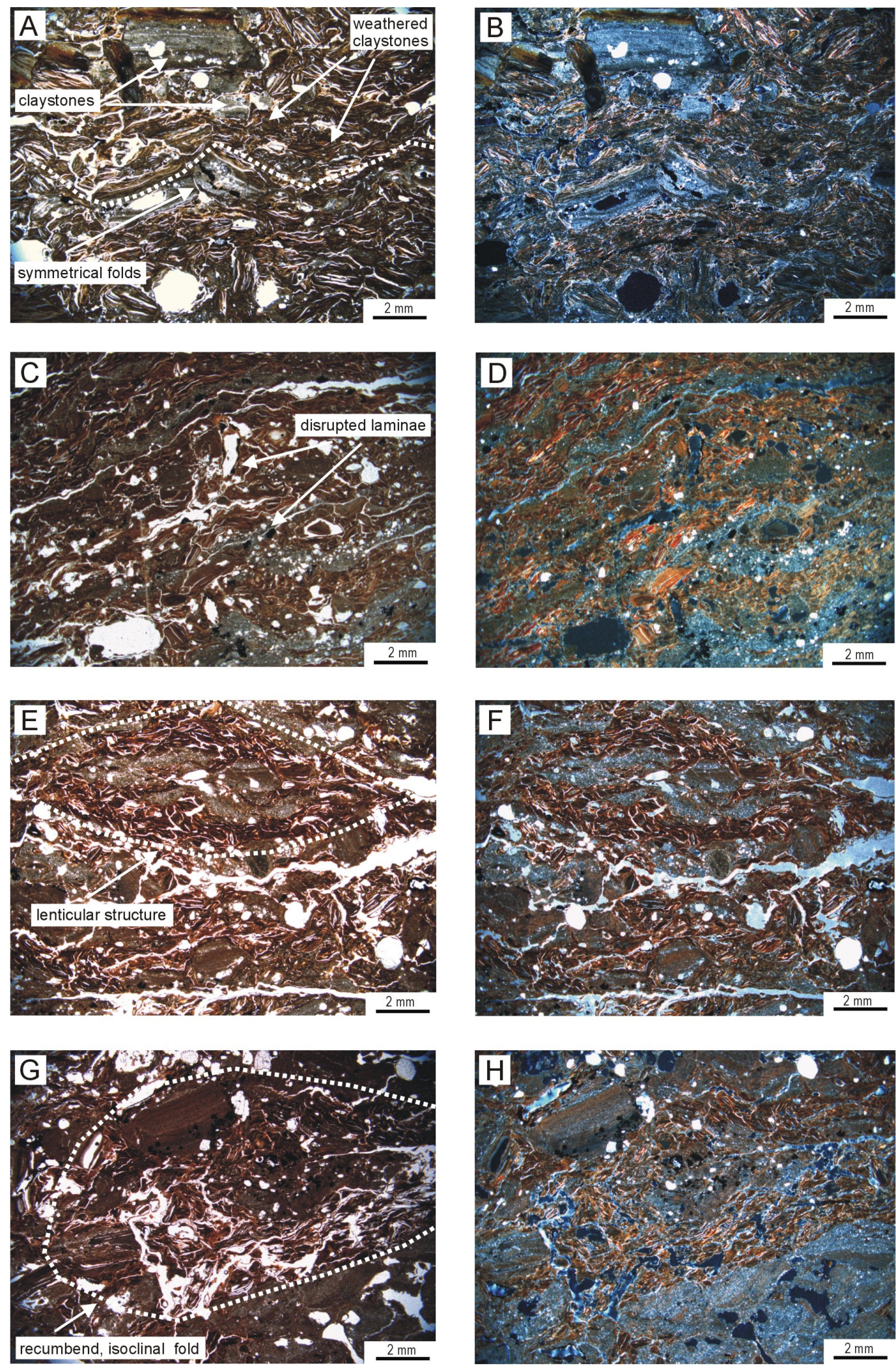

Fig. 6. Micromorphological features of unit IIa: A - diamicton, composed mainly of claystone and clayey matrix clasts. Symmetrical microfolds are visible (PPL- plane-polarised light); B - as A (XPL, cross-polarised light); C - laminated deposit, with disrupted laminae in places. Note the association of lamination and planar voids (PPL); D - as C in XPL; E - lenticular structure of clayey laminae (PPL); F - as E in XPL; G - recumbent, isoclinal fold. Note association of this structure and voids (PPL); $\mathbf{H}-$ as G in XPL 
are oriented similarly to the clasts in the clast pavement. Well-rounded gravels (up to $1 \mathrm{~cm}$ ) occur in places.

Microscopic analysis indicates that the diamicton is composed of claystone clasts up to $4 \mathrm{~mm}$ in diameter (Fig. 6A, B). Most of these clasts are strongly chemically weathered, and they contain microfissures which accentuate plate splitting. Single clasts of fresh/unweathered claystone are also found. Quartz grains derived from the sand and silt fractions are present in small amounts. Claystone clasts are predominantly angular to subangular in shape, while the sand grains are more rounded along edges. The matrix is clayey. Both claystone clasts and clayey matrix contain significant amounts of iron oxides/hydroxides. The deposit is characterised by distinct stratification/lamination (Fig. 6C, D). Non-graded, discontinuous laminae composed mainly of claystone clasts alternate with laminae composed mainly of fine-grained matrix. The contacts between them are sharp and wavy. Some laminae are brecciated. In places the laminae composed of claystone clasts form augen-like structures (Figs. 6E, F and 7F, G). In the deposit there are also microfolds, both symmetrical (Fig. 6A, B) and isoclinal, recumbent (Fig. 6G, H). The deposit is porous. Pores of planar void type dominate but vughs and vesicles are also found. Planar voids are of different sizes: 1) small fissures accentuating plate splitting of claystone clasts; 2) greater fissures running parallel to the contacts between laminae and to the boundaries of deformation structures, 3) great fissures unrelated to deposit structure. Masepic plasmic fabric predominates. Lattisepic and skelsepic plasmic fabrics occur in places. The contact between the diamicton and underlying sands of unit I is distinct, erosional, and locally deformed (Fig. 7A-G). A shear plane has been observed at this contact (Fig. 7B) and clay clasts and layers of clay occurring in the top of the sand unit (Fig. 7B-D). These layers are folded, stretched and boudinaged in places (Fig. 7C, D).

In the lower part of the diamicton, in the zone where sand lenses occur, the content of grains of fluvial origin, i.e., EM/EL and EL types altogether, amounts to $88 \%$, and only grains of OTHER and C types occur (in total 12\%) in association (Fig. 5A). A greater diversity of grain types is found in the upper part of the diamicton. The content of grains of fluvial origin (EL and EM/EL) decreases to 61\%, while that of grains of aeolian origin (RM and EM/ $\mathrm{RM}$ - in total $21 \%$ ) and grains of C type (6\%) increases.

Heavy-mineral grains occurring in the diamicton are poorly sorted and sharp-edged. Heavy- mineral analysis (Ludwikowska-Kędzia, 2013) indicates that opaque minerals predominate $(64-82 \%)$ (Fig. 5B). Primary iron oxides (mainly ilmenite) dominate in the lower part of the diamicton, while secondary iron oxides do so in the upper part. Secondary iron oxides (formed probably during pyrite oxidation) occur as small aggregates. They are easily crushed forming iron oxides silt. The content of transparent minerals is low. In the lower part of the diamicton, in the zone where sand lenses occur, transparent minerals constitute $36 \%$; in the main part of the diamicton only $18 \%$. The transparent mineral group is composed mainly of medium-resistant and non-resistant minerals (38-44\% and 32$37 \%$, respectively), mostly garnets and amphiboles. Resistant minerals (19-31\%) are mainly zircon, kyanite and tourmaline (Fig. 5B). The main heavy minerals follow the garnets $>$ amphiboles $>$ zircon (kyanite) scheme.

\subsubsection{Interpretation}

The diamicton has the features of a till that formed in a subglacial environment. Following classifications by Evans et al. (2006) and Benn \& Evans (2010), this diamicton may be interpreted as subglacial traction till, as follows:

1. Presence of a clast pavement, indicative of contact between ice and soft bed. This pavement could have formed on the bottom of the deformed layer by sinking of clasts into that, as is observed in debris flows (Clark, 1991). However, it could also have resulted from the selective removal of matrix from the diamicton by subglacial meltwater and moving ice. The clasts, which remained in the upper part of the layer, could have been buried by the accumulating diamicton (Boyce \& Eyles, 2000). Measured directional features indicate that the ice progressed locally from the southeast but these features do not allow us to draw conclusions about the direction of the advance of the ice-sheet/icesheet lobe in the Kielce-Łagów Valley.

2. Vertical changes in structural features of the diamicton, as well as force and style of its deformation, i.e., the occurrence of sand lenses in the lower part of the diamicton: pockets, sheets and stringers deformed by small-scale folding or faulting, small-scale thrusting and boudinage, replaced upwardly by a zone of subglacial accretion and sediment thickening.

The most important subglacial process behind the origin of sorted sands in diamictons is entrainment and deformation in the deforming layer (Hart \& Boulton, 1991; Phillips et al., 2008; Benn \& Evans, 2010; Phillips \& Lee, 2011). This could result from subglacial erosion of existing 

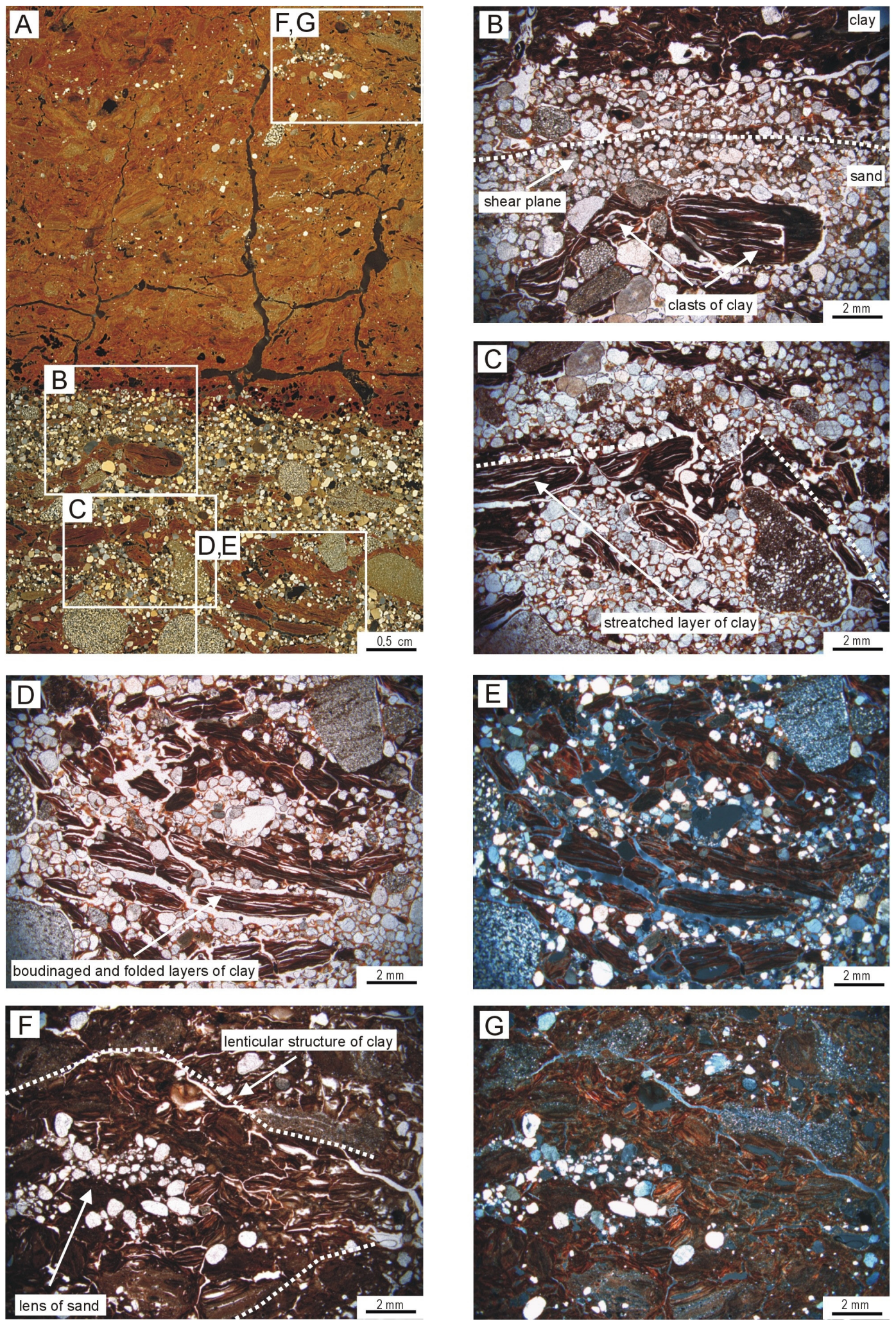

Fig. 7. Micromorphological features of contact between units I and IIa: A - thin section showing boundary between sands (unit I) and clayey diamicton (unit IIa). Note occurrence of large fissures the course of which is unrelated to deposit structure; shear plane occurring in the top of sands; B - clay clasts occurring in the top of sands (PPLplane-polarised light); C - stretched layer of clay within sands (PPL); D - boudinaged and folded layers of clay within sands (PPL); E - as D in XPL - cross-polarised light; F - lens of sand forming central part of lenticular structure of clay (PPL); G - as F in XPL 
sediments with a thickening of the deforming layer, or stretching and elongating (boudinage), or thrusting of sediments accompanied by movement in the deforming layer (cf. Waller et al., 2011). In each case sand deposits are subjected to strong deforming forces in the subglacial shear zone (Evans et al., 2006), which lead to their separation and elongation. For example, sand pockets, stretched and compressed, are transformed into stringers or thin sheets. Such types of sand lenses are commonly found in subglacial traction tills, although they may also be present in weakly deformed flow tills (Kessler et al., 2012). The occurrence of deformation structures, including small-scale thrusting, folding and shearing structures, suggests that the deposit was exposed to tensional stress developing along bedding planes as well as perpendicular compressional stress, and subsequently was deformed under actively moving ice. The process of boudinage occurs when sandy layers become stretched and elongated during deformation. Where this process is incomplete, the layers show a narrowing or necking, and the structure is referred to as pinch and swell (Figs. $3 \mathrm{~B}, 4 \mathrm{~B}$ ). This type of structure is useful as an indicator of the direction of extension within deformed sequences (Phillips \& Lee, 2011).

3. Occurrence of diamicton fragments (in the form of breccia?) in underlying sands, and occurrence of shear zones in the contact zone between these deposits suggest basal compression/squeezing and crushing of a probably frozen substrate by a moving glacier (Pederson, 2005; Kessler et al., 2012). These facts also indicate the temporarily increased role of subglacial water and suggest the existence of décollement zones at the ice-substrate contact (Evans et al., 2006; Piotrowski et al., 2006; Benn \& Evans, 2010).

Microstructures indicate planar movement associated with shearing. A detailed genetic interpretation, based on microfeatures observed, is disputable because all these features (lamination, budinage, folds, shear zone, types of plasmic fabric) are found both in debris flows and glacial tills (cf. Lachniet et al., 2001; Menzies \& Zaniewski; 2003, Phillips, 2006). However, the co-occurrence of such features is indicative of glacial till. For example, the lamination may be interpreted as having formed under ductile deformation during sediment flow - "laminar flow fabric" (according to Lachniet et al., 1999, 2001). However, laminated deposits form only as a result of strongly water-saturated flow, the development of which does not cause substrate deformation (Lachniet et al., 1999, 2001), while in the bottom of the deposit described there is a distinct deformation zone. This deposit is interpreted as subglacial till. Lamination in subglacial sediments forms as a result of lateral strain and secondary gravity loading (Hart \& Roberts, 1994; Roberts \& Hart, 2005; Menzies et al., 2006). The formation of laminated facies is possible under conditions of low to medium deformational strain. If strain had been higher, the stratified form would have been obliterated, resulting in more homogeneous massive sediments (Hart \& Roberts, 1994; Ruszczyńska-Szenajch et al., 2003). The structure of deposits studied (non-graded, discontinuous lamination, recumbent folds, décollement surface at base) corresponds to Type 1 laminae (sensu Roberts \& Hart, 2005), which are the product of primary extensional glaciotectonics, with ductile, intergranular, shear mechanism predominating. The occurrence of ductile deformations indicates relatively saturated conditions (cf. Menzies \& Maltman, 1992), whilst the incorporation of sand material into the laminated diamictic facies is a result of the upwardly directed hydraulic gradient (cf. Hart \& Roberts; 1994, Boulton et al,. 2001; Piotrowski et al., 2004a) combined with tectonic thrusting. Sediment porosity is altered by lateral shear, which in turn controls the structural geometry of the deforming bed. It is these rheological and structural controls that impact the hydraulic routing of pore water; the presence of open, interconnected fissures impacts the water content of till (Kilfeather \& van der Meer, 2008).

The occurrence of weathered claystone and sandy substrate clasts in the diamicton suggests that the weathered bedrock (Palaeozoic and/or Mesozoic) and sandy-gravelly deposits of unit I were the main source of material for diamicton formation. In the study area, near Górki Napękowskie, in the Radlin syncline (Filonowicz, 1969, 1976), and also in the southeastern part of the Kielce-Łagów Valley, claystones and siltstones, as well as Carboniferous clayey slates and bentonites, are exposed. The abundance of secondary iron compounds that have been formed during pyrite oxidation may be explained by the probable occurrence of Carboniferous rocks in the diamicton. Pyrite and ilmenite are the commonest iron minerals in the Carboniferous bentonites (e.g., Pawłowska, 1971). Macroscopic characteristics and mineral composition of the diamicton are similar to those of Triassic clays (Kubala-Kukuś et al., 2013) along the northern margin of the Holy Cross Mountains, in the belt stretching from Starachowice, via Suchedniów, Mniów and Radoszyce, to the Żarnów area south of Opoczno (see e.g., Wyszomirski \& Galos, 2009; Wyszomirski et al., 2006, 2010), i.e. to the north, northwest and 
northeast of the study area. From a petrographic point of view, these clays can be distinguished by their intensive cherry colour due to the occurrence of hematite. The similarity of the lower diamicton (unit IIa) to those deposits may be another indicator of the glacial origin of diamictons, and indirectly may reveal the direction of ice-sheet advance/ice movement (cf. Kosmowska-Sufczyńska, 1972; Kowalski et al., 1979; Ludwikowska-Kędzia \& Pawelec, 2011; Kubala-Kukuś et al., 2013).

Poor sorting and rounding of heavy mineral grains suggest short-lived transport, and thus support the relationship between the diamicton and Mesozoic/Palaeozoic bedrock. It is also confirmed by the mineral composition of the diamicton and features of minerals, i.e., the predominance of secondary iron minerals which formed during pyrite oxidation and occur as aggregates, as well as the low content of transparent heavy minerals.

The predominance of grains of fluvial origin in the diamicton indicates the erosion of sandy substrate and incorporation of sand into the deforming layer, where local deposits have been mixed with material transported over a great distance (Boulton et al., 2001; Benn \& Evans, 2010). But, the increasing content of grains of aeolian origin in the upper part of unit IIa suggests the development of aeolian processes which probably accompanied ice-sheet advance. The scheme of the main heavy minerals in the diamicton resembles that are considered to be typical of tills in Poland (cf. Racinowski, 2010).

\subsubsection{Unit IIb. Upper diamicton}

The upper diamicton $\operatorname{DSm}\left(m_{2}\right)$ is massive, brown (Figs. 3, 4F). It is a matrix-supported deposit, with a moderate content of clasts. The skeleton is formed by well-rounded gravels, mainly medium- and coarse-grained, granite boulders (size 30x18 cm) with smoothed and striated surfaces, some with wedge striae, and boulders/clasts with stoss-andlee forms (Fig. 4G). Sharp-edged fragments (size $30 \times 15 \mathrm{~cm}$ ) of sandstones occur in places. The matrix of the diamicton is sandy, locally sandy-clayey (Fig. $4 \mathrm{H})$.

In places, in face II, the diamicton contains blocks (size $15 \times 25 \mathrm{~cm}$ ) composed of fine and varigrained sands (Fig. 3D, 4H). Sands have different colours, and the boundary between colours is sharp. Sands in the upper part are yellow to light grey, and in the lower part brown to rust-coloured, and enriched in the silty-clayey fraction. In the upper part of the diamicton the sand blocks are massive, oval in shape, with rounded edges. In contrast, some blocks occurring at the boundary between the diamictons are elongated, with uneven edges, and with internal structure in the form of veinlets filled with white sands preserved (Fig. 3D, 4H). Sand blocks are oriented differently in the diamicton: vertically, obliquely and even horizontally.

The contact between the upper (unit IIb) and lower diamicton (unit IIa) is deformational, loaded, in places with sharp-edged sandy blocks (Figs. 3D, $4 \mathrm{H})$. The top of the upper diamicton is uneven, also deformational, with visible diapiric forms, undulations and erosional surfaces (Figs. 3A-D, 4I). The diapiric forms are inclined from north to south (in face I) or from east to west (in face II).

Microscopic images show a diamicton with high grain density and low matrix or clay density. Grain clusters are numerous (Fig. 8A, B). The silt grains are predominantly angular to subangular in shape, while the larger grains have more rounded edges. Rotational structures with a diameter of $1-3 \mathrm{~mm}$ are visible. Locally, they are associated with short lineaments, which consist of at least three aligned grains (Fig. 8C, D). Planar voids, which are parallel to lineation, and crushed grains are found near these grain lineaments. Small water-escape structures occur in the entire deposit. The voids are mainly planar. As mentioned above, they are locally associated with lineaments. However, on most thin-section surfaces they are randomly distributed. A marble structure is observed, in which the deposit consists of a number of separate aggregates delineated by voids (cf. van den Meer 1993) (Fig. 8A, B, E, F). There are also pores of vugh and vesicle type. Voids and water-escape structures are often associated with iron staining. The deposit contains inserts of strongly weathered claystones, similar to unit IIa (Fig. 8G, $\mathrm{H})$ described above. These inserts occur as laminae that are strongly deformed (stretched and brecciated) in places. Plasmic fabric pattern is diverse masepic plasmic fabric predominates, but lattisepic and skelsepic fabrics are also found.

In the lower part of the diamicton the content of grains of fluvial origin, i.e.. EL and EM/EL types, is $64 \%$ (Fig. 5A), and in addition only grains of OTHER $(30 \%)$ and C (3\%) types occur. Grains of aeolian origin (RM and EM/RM) are found sporadically $(2 \%)$. Greater diversity of grain types is found in the upper part of the diamicton. The content of grains of fluvial origin (EL and EM/EL) decreases to 26\%, while grains of aeolian origin (30\%) and type C $(6 \%)$ occur in greater amounts.

Heavy-mineral analysis (Ludwikowska-Kędzia, 2013) indicates that the deposit is characterised by only a slightly higher percentage of transparent minerals $(55-58 \%)$ than that of opaque minerals $(42-45 \%)$ (Fig. 5B). Grains of transparent heavy minerals are poorly sorted and poorly rounded, 

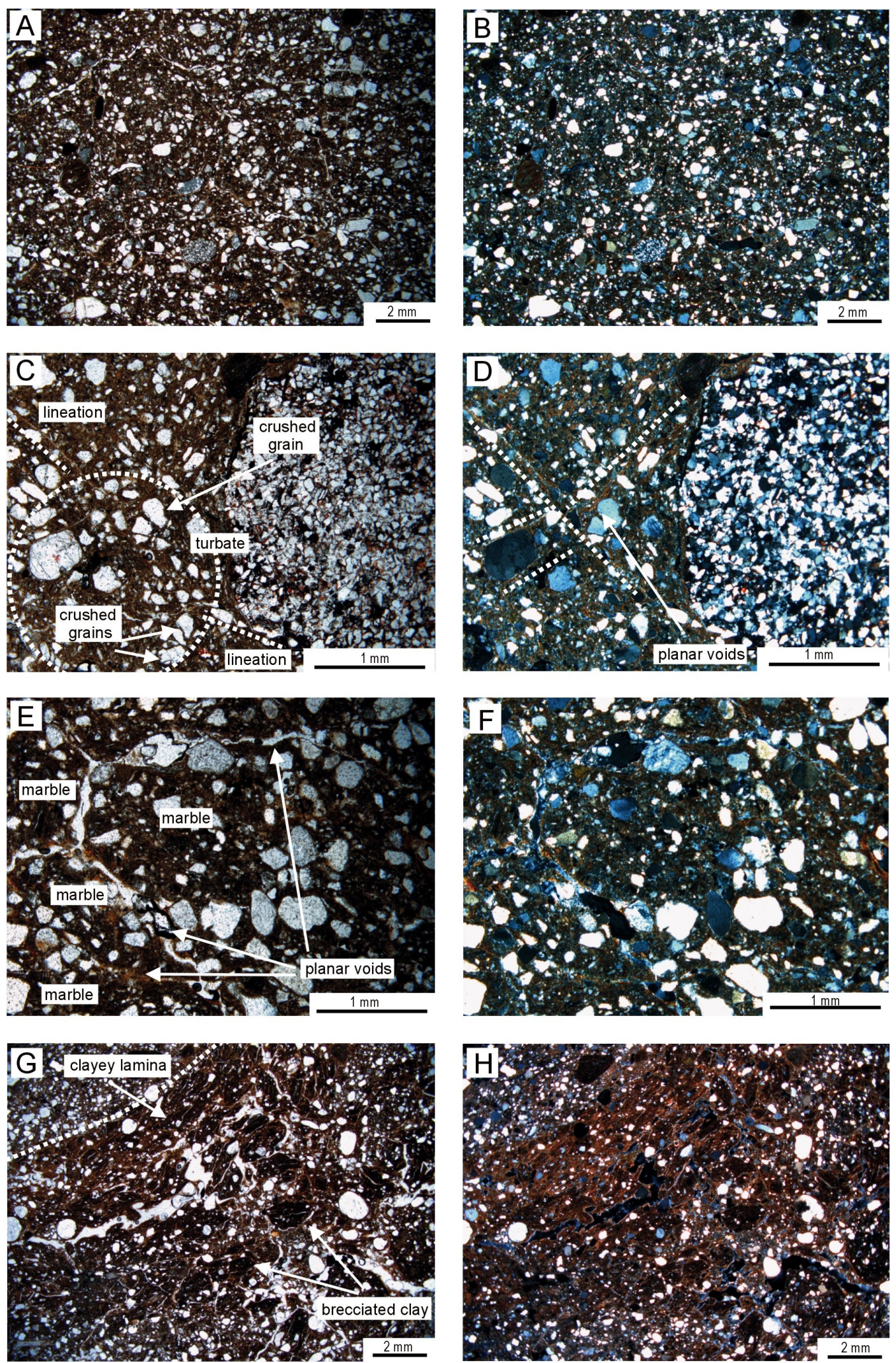

Fig. 8. Micromorphological features of unit IIb: A - diamicton with high grain density and low matrix or clay density. Note randomly scattered open planar voids (PPL - plane-polarised light); B - as A in XPL - cross-polarised light; C - rotational structure associated with short lineaments, and crushed grains (PPL); D - as C in XPL, visible planar voids filled with anisotropic material, and associated with lineaments; E - marble bed microstructure - aggregates delineated by voids (PPL); F - as E in XPL; G - clayey insert in diamicton, occurring as laminae that are stretched and brecciated in places (PPL); $\mathbf{H}-$ as G in XPL. 
with fragments of other minerals, joined within a primary rock. Grains of opaque minerals have similar features. They are very irregular in shape, and have a diverse composition. Some of them are easily crushed forming fine silt. Rounded grains of ilmenite occur in small amounts. The mineral composition in the lower and upper part of the diamicton is different (Fig. 5B). Semi-resistant minerals $(47 \%)$, represented by garnets and epidotes, predominate in the lower part. The amounts of other groups are similar: resistant minerals, represented mainly by zircon, make up $28 \%$, and non-resistant ones, represented mainly by amphiboles, 5\% (Fig. 5B). Resistant minerals (47\%), mainly zircon, predominate in the upper part of the diamicton where the content of semi-resistant garnets and epidotes is high as well (40\%). The content of non-resistant minerals, i.e. amphiboles, is the lowest (13\%). Opaque minerals are represented mainly by secondary iron oxides, the content of which ranges from 24 to $28 \%$. The amount of primary iron oxides is low (14-21\%). The main heavy minerals follow the garnets $>$ amphiboles $>$ zircon (epidotes) or zircon $>$ garnets $>$ amphiboles scheme.

\subsubsection{Interpretation}

The high degree of deposit homogenisation, the occurrence of Scandinavian erratics with features indicating their former presence in traction zone (i.e., erratics are elongated and flat, with smoothed and striated surfaces, wedge striae, and stoss-andlee forms) (cf. Krüger, 1984; Benn, 1995), and microstructural features indicate subglacial conditions of formation.

Microscopic analysis indicates that the deposit studied is characterised by both brittle and ductile deformation. Turbates and necking structures are indicative of grain rotation and squeeze flow of sediment between grains under moist conditions, while microshears and crushed grains suggest microshearing and grain fracturing occurring under well-drained conditions (Menzies, 2000; Larsen et al., 2006). The presence of both types of microstructures in subglacial tills may be indicative of temporal and/or spatial changes in pore-water pressure within the till matrix (e.g., Hiemstra \& van der Meer, 1997; Hart, 2006; Piotrowski et al., 2006; Menzies \& Brand, 2007; Menzies, 2012). Turbate grain arrangements are indicative of rotational movements of grains (van der Meer, 1993, 1997; Hiemstra, 2001; Hiemstra \& Rijsdijk, 2003). They are locally associated with short lineaments of grains and planar voids, which may suggest the development of subglacial shear (Hiemstra \& Rijsdijk, 2003). The occurrence of clayey inserts indicates the process of cannibalisation of the substrate. However, the oc- currence of turbates, occasionally associated with short lineaments, does not indicate a systematic or pervasive subglacial shear regime (Evans \& Hiemstra, 2005). Skeletal grain orientations do not seem to have been influenced by planar void orientations in most thin sections. This indicates that most planar voids are fractures rather than shear planes. This inference is supported by the fact that planar voids in most thin sections are randomly rather than preferentially oriented in response to a unidirectional shear stress field (cf. Hiemstra \& Rijsdijk, 2003; Menzies, 2012). Marble bed structures formed under different subglacial conditions. The zone of shearing can change from the marble bed configuration, to one that consists of rotational structures and skelsepic plasmic fabric (van der Meer et al., 2003). There is also a view that marble bed and turbate structures formed in reverse order. The process of marble bed formation destroys turbate and linear structures by breaking them apart, when shear is the predominant deforming factor, and water pressures are not high (Kilfeather et al., 2008). Moreover, it is possible that the fractures occurring in the deposit in part formed during desiccation and frost processes in the till after deposition. To summarise, the co-occurrence of microstructural features in the deposit studied indicates subglacial till formed under conditions of changes in pore-water pressure within the till matrix. Such conditions are typical of tills formed in the submarginal environment, in which the shear indicators are obliterated owing to superimposed processes connected with pore-water movement, conditioned by climate (cf. Evans \& Hiemstra, 2005).

The deformational nature of the diamicton bottom is interpreted as being due to loading caused by materials being released by melting (cf. Evans et al., 2006; Benn \& Evans, 2010). The occurrence of sand blocks with preserved internal structure at the boundary between the diamictons may also indicate subglacial melting of material torn by ice sheet from a frozen substrate. The deformation in the top of the diamicton took place under uncertain conditions. The visible diapiric forms, undulations and oval-shaped, massive sand blocks (resembling drop structures) should be related to unstable density stratification - depositional or non-depositional (cf. Butrym et al. 1964; Dżułyński, 1966; Anketell et al., 1970; Cegła \& Dżułyński, 1970; Harris et al., 2000). The formation of depositional systems with unstable density stratification was favoured by the contact of the diamicton with sands (deposits susceptible to liquefaction), melting of ice sheet, and probable occurrence of permaforst in the substrate that hindered water infiltration and resulted in peri- 
odic, strong water-saturation of deposits. Non-depositional unstable density systems could also have formed in the deposits studied, mainly during permafrost melting (Butrym et al., 1964; Harris et al., 2000).

The visible inclination of the diamicton diapiric form and stretching of its upper part in the sands (face A) are indicators of conditions under which these deformations, triggered by unstable density stratification, formed. They could be the result of lateral pressure exerted by e.g., flowing water friction, or by gravitational slope processes where deposits occur on a slope.

The mineral composition of the diamicton, and the roundness and frosting of quartz grains in it, are typical of tills in Poland (cf. Racinowski, 2010; Woronko, 2012). The very poor rounding of minerals, their occurrence in the form of aggregates and the presence of xenoliths of the lower diamicton (unit IIa) suggest glacial erosion of the lower diamicton, connection of the upper diamicton with Palaeozoic and Mesozoic bedrock, and short-lived transport of material. Sandy material occurring in the upper diamicton was probably deposited by supra- and/or inglacial meltwater.

In the upper part of the diamicton a high content of grains of the EM/RM type was found. This suggests favourable conditions for the development of short-lived aeolian processes synchronous with diamicton material supply. The considerable amount of transparent resistant heavy minerals, secondary iron oxides, and grains of OTHER type indicate that the deposit was subjected to in situ post-depositional weathering processes.

\subsection{Unit III. Sands with gravel-debris layer}

Deposits of unit III occur on the ground surface and cover the diamicton series. They consist of three lithofacies: massive sand $S m$, massive gravel/ debris G-Bm and deformed sand $S d$ (Fig. 3A-D).

Lithofacies $S m$ is composed mainly of yellow medium- and fine-grained sands with single gravel clasts. Its thickness ranges from 30 to $50 \mathrm{~cm}$. The contact of sands with the underlying diamicton (unit IIb) is deformational. The sands are covered by or pass horizontally into gravel-debris deposits G-Bm (Fig. 3D, 4K-L) and are composed of medium and coarse, well-rounded gravels and sharp-edged debris (6-15 $\mathrm{cm}$ in diameter).

Lithofacies $S d$ consists of yellow (white in places) sands with thin, rust-brown, iron-rich laminae (up to $2 \mathrm{~cm}$ thick), and an iron-rich layer (10-15 $\mathrm{cm}$ thick) at the bottom (Figs. 3C, 4I). The degree of bending of laminae decreases upwards, and in the near-surface zone they run horizontally. Sands between the laminae display a massive structure. This lithofacies is $50-70 \mathrm{~cm}$ thick. Its contact with the diamictons of unit II is sharp and erosional. Erosional dissections, in places filled with brown, massive silty sand, are visible in the top of lithofacies Sm and $S d$ (Fig. 3C).

Lithofacies $S d$ is characterised by a predominance of quartz grains of aeolian origin of EM/RM type (74\%) (Fig. 5A). The content of typical aeolian grains RM is low (4\%). The content of grains of fluvial origin (EL and EM/EL) is only $7 \%$, while grains of OTHER type constitute 15\%.

The mineralogical composition of the heavy fraction is characterised by a predominance of transparent minerals (71\%) (Ludwikowska-Kędzia, 2013) (Fig. 5B). Grains of both transparent and opaque minerals are very well sorted and well rounded. Opaque minerals are represented mainly by primary iron oxides - ilmenite and magnetite - constituting $27 \%$, while the content of secondary iron oxides is only $1.6 \%$. Semi-resistant minerals (58\%) - mainly garnets and epidotes - predominate in the group of transparent minerals. Resistant minerals, represented mainly by zircon and staurolite, constitute $28 \%$. The content of non-resistant minerals, i.e., amphiboles and pyroxenes, is 13\% (Fig. 5B). The main heavy minerals follow the garnets $>$ amphiboles $>$ zircon (staurolite, epidotes) scheme.

\subsubsection{Interpretation}

These deposits may be interpreted as having been transported and deposited by glacial meltwater. Gravel/debris material was released from the ice, together with water during ice-sheet stagnation/decay(?).

With respect to properties and proportions of heavy minerals, these deposits resemble the sands of unit I. However, they show the following features of periglacial transformation:

1. A predominance of quartz grains of the EM/RM type, the occurrence of well-rounded and sorted heavy-mineral grains as well as the scheme of main heavy minerals, which is typical of dune deposits (cf. Mycielska-Dowgiałło, 1995, 2007; Racinowski, 2010; Woronko, 2012). It provides a record of the relatively brief impact of aeolian processes (cf. Mycielska-Dowgiałło, 1996, 2001; Woronko, 2001, 2012). The sandy lithofacies $S d$, Sm represent aeolian sand cover.

2. A near-surface accumulation of coarse-grained deposits $G-B m$ as a result of frost-heave processes. These deposits were exposed by aeolian processes as deflation pavement (Fig. 4K). 
3. A deformational and erosional contact between these deposits and underlying diamictons - the first one is a record of the existence of depositional or non-depositional unstable density stratification system in periglacial conditions, the latter indicating erosion of the glacigenic deposit cover. The erosional dissection, visible in the top of the exposure, was filled with silty sand, which was washed out (and blown) not only from the sands of unit III but also from diamictons of unit II.

4. The occurrence of rust-coloured laminae and layers with accumulated iron compounds in the sands $S d$, which must have been related to weathering processes. Laminae of such type, named illuvial bands (Prusinkiewicz et al., 1998), illuvial clay lamellae (Johnson et al., 2008) or lamellae (Rawling, 2000; Holliday \& Rawling, 2006; Bockheim \& Hartemink, 2013), are commonly found in sandy soils in a variety of environments (especially often in dunes and outwash plains). They can have geological (depositional) or pedologic origin (argilluviation, frost migration), or they may form both by geological and pedological processes (Rawling, 2000). It is probable that in this particular case the lamellae may reflect concurrent deposition of sand and pedogenesis under conditions of permafrost decay.

\section{Depositional conditions of strata}

The deposit complex studied is a record of fluvioglacial and glacial deposition as well as postglacial transformation under periglacial conditions.

The accumulation of sandy and gravelly deposits (unit I) preceded the stage of ice-sheet/icesheet lobe(?) advance, representing a fluvioglacial environment of a shallow, sand-bed braided river. "Older" alluvia, and weathered local bedrock, were the source of material transported by this river. The river channel was characterised by an undulating bed relief and rapid changes of water level. Transverse sand bars, formed in shallow zones of the channel, were washed out during short flood flows.

The advancing ice sheet encroached on the area of fluvioglacial accumulation, in which permafrost processes occurred. The ice sheet eroded and deformed local bedrock, and this caused mixing and homogenisation of deposits, both local and transported over a long distance. The diamictons (unit II) formed under subglacial conditions during the same glacial episode. They are interpreted as sub- glacial traction till (cf. Evans et al., 2006; Benn \& Evans, 2010). The diamictic material was released directly from the substrate and/or from the ice, and then homogenised, completely or to some extent, by different subglacial processes of deposition, deformation and melting. These complex, subglacial processes of deposition and deformation were variable in time and space (e.g., Dreimanis, 1989; van der Meer et al., 2003; Evans et al., 2006; Piotrowski et al., 2004b, 2006; Benn \& Evans, 2010). Their variability was conditioned, among other things, by the diverse relief of the sub-Quaternary surface (cf. Lamparski 1970; Lindner \& Ruszczyńska-Szenajch, 1977), the co-occurrence of soft and hard substrates with different lithology (cf. Evans et al., 2006), changes in ice-sheet/ice-sheet lobe thickness (e.g., Różycki, 1972a), or the occurrence of permafrost. These conditions could have resulted in one place in the detachment of ice from the substrate and formation of stratified diamicton, and in the development of deformational layer only in an other (cf. Evans et al., 2006; Benn \& Evans, 2010; Kessler et al., 2012; Narloch et al., 2012, 2013). It seems that the depositional conditions of the deposits studied from the Kielce-Łagów Valley are similar to those described in the model of subglacial till formation by several deposition-deformation processes (Piotrowski et al., 2004b, 2006), varying in time and space. Therefore, the resultant subglacial tills may be of different facies, although formed and deposited during the same glacial episode.

The cover of diamictons by sands and sandy gravels (unit III) should be related to periodic activity of meltwater during ice-sheet stagnation and probable decay (cf. Krüger et al., 2010). The surface of glacial accumulation, formed in this way, was conducive to the development of deformations (cf. Jahn, 1951; French, 1996), which is connected with the existence of depositional and non-depositional unstable density stratification systems. With time this surface was subjected to erosion-denudation and aeolian processes, and recorded the results of postglacial climate changes. During a gradual climate change towards more severe conditions (resulting in lower infiltration rates due to ground freezing and subsequent permafrost development) the accumulation surface was dissected as a result of activation of denudation processes. Later, during permafrost degradation, conditions became favourable for the infilling of the dissections with deposits, among others cover sands, which formed due to activation of aeolian processes (cf. Kasse et al., 2003; Turkowska, 2006; Goździk, 2007; Woronko, 2012). 


\section{Chronostratigraphy}

Four samples of fluvioglacial unit I were OSL dated at 147.0+/-8.1 $\mathrm{ka}$ (GdTL-1462), 189.0+/-1.1 ka (GdTL-1459), 209.0+/-1.2 ka (GdTL-1463), and 251.0+/-1.8 ka (GdTL-1461) (Fig. 9). Results obtained indicate that these deposits formed during the Middle Polish Complex (Saalian). More precisely, according to Lindner \& Marks (2012), it was the period including the Lublinian Interglacial (Saalian, Schoningen, MIS 7) and Odranian Glaciation (Saalian, Drenthe, MIS 6). The OSL dating obtained for the cover sands of unit III, i.e. $47.8+/-3.2$ ka (GdTL-1460), indicates that they belong to the North Polish Complex, Vistulian Glaciation, Middle Plenivistulian (Weichselian, MIS 3).

Based on results of OSL dating, and according to current stratigraphy of the Pleistocene in the Holy Cross region (Lindner, 2004), braided rivers deposited the alluvia of unit I under interglacial conditions of the Lublinian Interglacial (Schönningen, Saalian MIS 7) and under periglacial conditions of the Odranian Glaciation (Drenthe, Saalian, MIS 6). The textural features of these deposits indicate their fluvioglacial origin. These inter/periglacial conditions were conducive to the redeposition of older fluvioglacial/fluvial alluvia of the South Polish Complex (Cromerian) and formation of inter/per- iglacial series of fluvial deposits. However, in this case we could expect more "weathered", and above all wind-blown, deposits (cf. Goździk, 2001; Mycielska-Dowgiałło, 2001; Woronko, 2012). Deposits of unit I do not have such features. Maturity of the detrital material of unit I, which is visible in features of mineral spectrum of these alluvia, was not solely a result of their repeated redeposition. The source deposits for these alluvia were, among other things, weathered Palaeozoic, Mesozoic and Paleogene-Neogene rocks of the Holy Cross Mountains. The newly formed alluvia inherited the features of mineral composition from those rocks.

The sandy deposits and gravel-debris layer of unit III record the release of glacial material from melting ice during ice-sheet stagnation/decay, but mainly of erosion-denudation transformation of inherited glacigenic deposits in the Middle Plenivistulian (Interpleniglacial) (Weichselian, MIS 3). The interpretation of structural and textural features of these deposits corresponds to their stratigraphic position, which has been determined based on results of OSL dating. They formed in a period that was initially characterised by a predominance of erosion at the valley bottoms. A dense net of small denudation valleys developed even in areas with small differences in elevation. Subsequently followed the stage of especially intensive wash processes (e.g.,

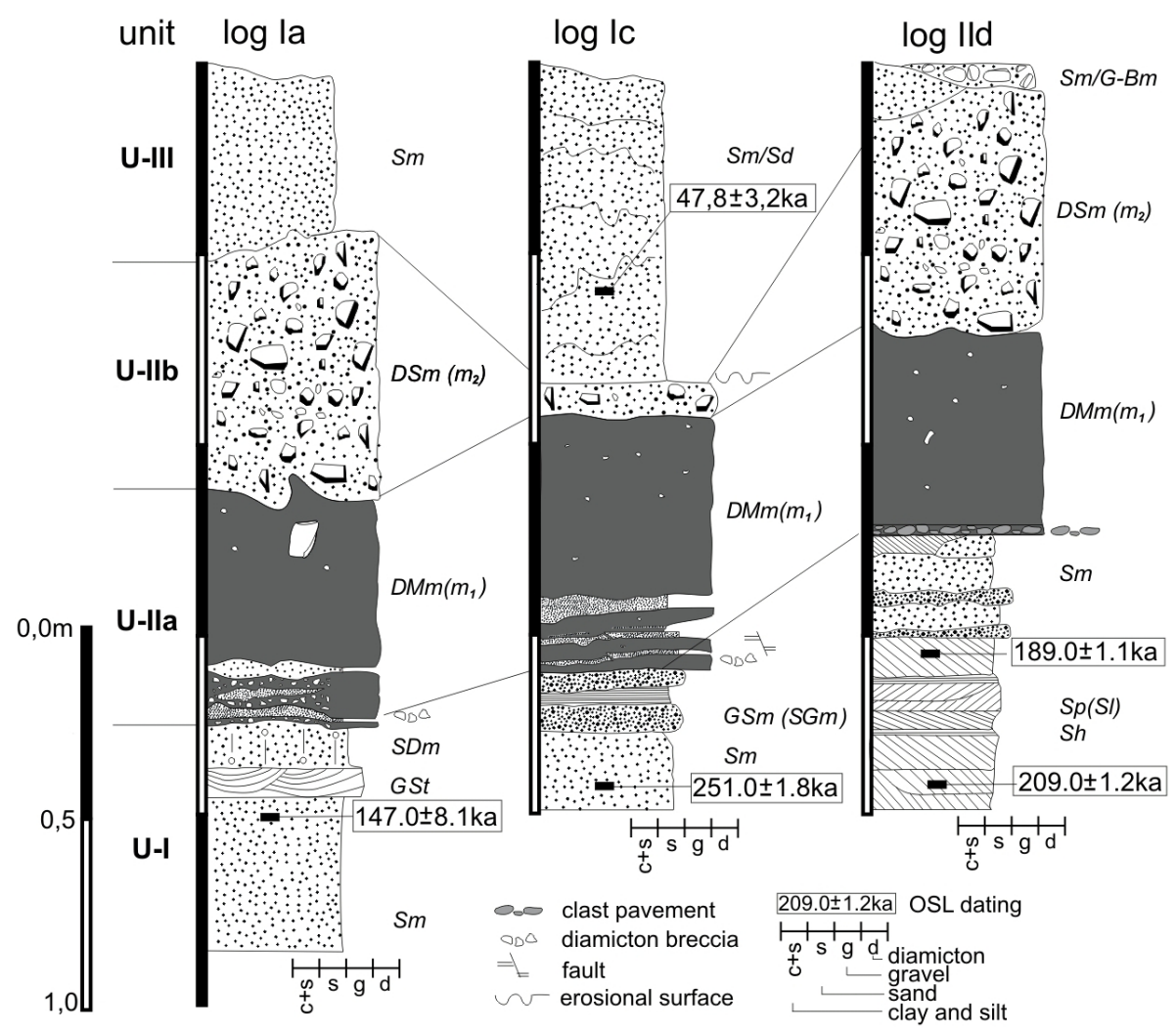

Fig. 9. Sedimentological log and OSL age of deposits 
Dylik, 1972; Turkowska, 2006). The disappearance of permafrost is indicated by the deformational contact between these deposits and the underlying diamictons, and the occurrence of iron-rich lamellae as a sign of geological-pedological processes. A high content of aeolian grains in these deposits indicates an intensification of aeolian processes under periglacial conditions.

Based on OSL dating obtained for the sandy deposits of units I and III, the diamicton series of unit II should be linked to the Odranian Glaciation (Saalian, Drenthe, MIS 6). Such a conclusion about the age of unit II is at variance with the extent of the Odranian ice sheet in the Holy Cross region (cf. Lindner, 2004; Lindner \& Marks, 2012) (Fig. 1A) because it indicates the occurrence of this ice sheet on the southern flank of the Eysogóry mountain range. However, it does correspond to an opinion expressed by several researchers who studied the Pleistocene palaeogeography in the central and south-eastern part of the Holy Cross Mountains, and who assumed that the ice sheet of the Middle (Saalian) Glaciation (treated as a single glacial episode at the time) reached further south and extended across the Kamienna River valley, and even the Łysogóry (among others: Czarnocki, 1927, 1931; Kotański, 1959; Walczowski, 1968; Kosmowska-Sufczyńska, 1972; Filonowicz, 1980). However, the results of the present study which question the origin and age of tills in the Holy Cross Mountains do not stand alone (cf. Sołtysik, 1998, 2002). They seem to be all the more probable because the extremely long-lasting and severe conditions of the Saalian (e.g., Bard et al., 2002) favoured the maintenance of the maximum extent (from pre-160 ka) of the Eurasian ice sheets during the Late Saalian (160-140 ka) (e.g., Colleoni et al., 2009). That is why the issue of the extent of the Odranian ice-sheet lobes in the Holy Cross Mountains needs further, detailed lithogenetic and lithostratigraphical studies of glacigenic deposits in the region.

\section{Conclusions}

Structural and textural features of the deposit complex studied indicate that it records a glacial and postglacial cycle. The occurrence of subglacial tills overlying fluvioglacial sands and gravels points to the existence of ice cover in the area of the Kielce-Łagów Valley (central part of the Holy Cross Mountains). The occurrence of an erosion-denudation surface in the top of glacigenic deposits indicates their transformation under postglacial (interglacial-interstadial?)/periglacial conditions.
Facies diversity of subglacial tills dating from the same glacial episode resulted from the fact that they formed at the base of active ice deposition-deformation processes that varied in time and space. These processes were conditioned mainly by the diverse relief of the sub-Quaternary surface in the Kielce-Łagów Valley, and thereby the spatially varying arrangement of hard and soft substrates, and the occurrence or absence of permafrost.

The cover of diamictons by sandy and sandy-gravelly deposits should be related to accumulation of melt-out material. Such conditions led to deformation of glacigenic deposits due to the formation of depositional and non-depositional unstable density stratification systems. The transformation of the deposit complex was completed under periglacial conditions by complex, erosion-denudation and aeolian processes.

Mineralogical and petrographical features of the deposits, as well as the degree of rounding and frosting of quartz grains, confirm the genetic relationship of the deposits studied with the sub-Quaternary bedrock, glacial environment and periglacial transformation conditions.

The OSL ages obtained for these deposits correspond with the genetic and palaeoenvironmental interpretation of their structural and textural features. It suggests that the complex of glacigenic deposits formed partially at the end of the Lublinian Interglacial (Saalian, Schöningen, MIS 7), generally - during the Odranian Glaciation (Saalian, Drenthe, MIS 6), and transformed under periglacial conditions during the Vistulian Glaciation, i.e. in the Middle Plenivistulian (Weichselian, MIS 3). This stratigraphic position of the diamictons is inconsistent with the commonly accepted Pleistocene palaeogeography of the Holy Cross region (with the extent of the Odranian ice sheet). The results of the present study indicate the need for continued detailed research on the origin and age of glacigenic deposits in the central part of the Holy Cross Mountains, and have an impact on the issue of the extent and course of Pleistocene glaciations.

\section{Acknowledgements}

This work has been financially supported by the Polish Ministry of Science and Higher Education (project no. N306 129337). We are grateful to Dr hab. Barbara Woronko for carrying out the analysis of roundness and frosting of quartz grains, and to Dr Eng. Bogusław Marcinkowski for performing a heavy-mineral analysis. 


\section{References}

Anketell, J.M., Cegła, A.J. \& Dżułyński, S., 1970. On the deformational structures in system with reversed density gradient. Annales Societatis Geologorum Poloniae $40,3-30$

Barczuk, A. \& Nejbert, K., 2007. Analiza minerałów nieprzezroczystych w badaniach skał okruchowych [Analysis of opaque minerales in the clastic rocks]. [In:] E. Mycielska-Dowgiałło \& J. Rutkowski (Eds): Badania cech teksturalnych osadów czwartorzędowych $i$ wybrane metody oznaczania ich wieku [Research into the textural features of Quaternary sediments and some dating methods]. The Family Alliance School of Higher Education Press, Warsaw, 205-228 (in Polish).

Bard, E., Antonioli, F. \& Silenzi, S., 2002. Sea-level during penultimate period based on a submerged stalagmite from Argentarola Cave (Italy). Earth and Planetary Science Letters 196, 135-146.

Benn, D.I., 1995. Fabric signature of subglacial till deformation, Breidamerkurjökull, Iceland. Sedimentology 42/5, 735-747.

Benn, D.I. \& Evans, D.J.A., 2010. Glaciers and Glaciation, 2nd edition. Hodder Education, London, England.

Bockheim, J.G. \& Hartemink, A.E., 2013. Classification and distribution of soils with lamellae in the USA. Geoderma 206, 92-100.

Boulton, G.S., Dobbie, K.E. \& Zatespin, S., 2001. Sediment deformation beneath glaciers and its coupling to the subglacial hydraulic system. Quaternary International 86, 3-29.

Boyce, J.I. \& Eyles, N., 2000. Architectural element analysis applied to glacial deposits: internal geometry of a Late Pleistocene till sheet, Ontario, Canada. Geological Society of America Bulletin, 112: 98-118.

Brewer, R., 1964. Fabric and Mineral Analysis of Soils. John Wiley, New York., 470pp.

Butrym, J., Cegła, J., Dżułyński, S. \& Nakonieczny, S., 1964. Nowa interpretacja "struktur peryglacjalnych" [New interpretation of "periglacial structures"]. Folia Quaternaria 17, 1-34.

Cailleux, A., 1942. Les actiones éoliennes périglaciaires en Europe. Mémoires de la Société géologique de France, 41, 1-176.

Carr, S.J., 2004. Micro-scale features and structures. [In:] D.J.A. Evans \& D.I. Benn (Eds): A practical guide to the study of glacial sediments, Arnold, London, 115-144.

Cegła, J. \& Dżułyński, S., 1970. Układy niestatecznie warstwowane i ich występowanie w środowisku peryglacjalnym. [System with reversed density gradient and their occurrence in periglacial zones]. Acta Universitatis Wratislaviensis 124,17-40.

Clark, P.U., 1991. Striated clast pavements: products of deforming subglacial sediments? Geology 19, 530-533.

Colleoni, F., 2009. On the Late Saalian glaciation (160-140 ka): a climate modeling study. Climatology. Universitet Joseph-Fourier-Grenoble I; Stockholm University, 184pp.

Czarnocki, J., 1927. O zlodowaceniach środkowej części Gor Świętokrzyskich [About Glaciations of the central part of the Holy Cross Mountains]. Posiedzenia naukowe Panstwowego Instytutu Geologicznego 17, 18-21.

Czarnocki, J., 1931. Dyluwium Gór Świętokrzyskich. [Diluvium of the Holy Cross Mts.] Rocznik Polskiego Towarzystwa Geologicznego 7, 82-105. (in Polish, with German summary).

Czarnocki, J., 1950. Geologia regionu łysogórskiego. [Geology of the Łysa Góra Region]. Prace Państwowego Instytutu Geologicznego 1, 404pp. (in Polish, with English summary).

Czarnocki, J., 1957. Tektonika Gór Świętokrzyskich. Stratygrafia i tektonika Gór Świętokrzyskich. [Tectonic of the Holy Cross Mountains. Stratigraphy and tectonic of the Holy Cross Mountains]. Prace Państwowego Instytutu Geologicznego, 18, 133pp. (in Polish, with English summary).

Dreimanis, A., 1989. Tills: their genetic terminology and classification. [In:] R.P. Goldthwait \& S.L. Matsch (Eds.): Genetic Classification of Glacigenic Deposits. Balkema, Rotterdam, 17-83.

Dylik, J., 1972. Znaczenie spłukiwania w morfogenezie peryglacjalnej [The importance of runoff in the periglacial morphogenesis]. Prace Komisji Geograficzno-Geologicznej 13/1, 99-119.

Dżułyński, S., 1966. O strukturach sedymentacyjnych związanych z niestatecznym warstwowaniem gęstościowym [Sedimentary structures resulting from convection-like patterns of motion]. Rocznik Polskiego Towarzystwa Geologicznego 36, 3-21. (in Polish, with English summary).

Evans, D.J.A. \& Hiemstra, J. F., 2005. Till deposition by glacier submarginal, incremental thickening. Earth Surface Processes \& Landforms 30, 1633-1662.

Evans, D.J.A., Phillips, E.R., Hiemstra, J.F. \& Auton, C.A., 2006. Subglacial till: Formation, sedimentary characteristics and classification. Earth-Science Reviews, 78, 115-176.

Filonowicz, P., 1969. Objaśnienia do Szczegótowej mapy geologicznej Polski w skali 1:50000, ark. Bodzentyn [Explanations to the Detailed Geological Map of Poland 1:50000, Bodzentyn sheet]. Warszawa, 86pp.

Filonowicz, P., 1972. Plejstocen na obszarze południowo-zachodniej części Gór Świętokrzyskich [Pleistocene deposits in the SW part of the Holy Cross Mts]. Rocznik Polskiego Towarzystwa Geologicznego 42, 105-116.

Filonowicz, P., 1976. Objaśnienia do Szczegótowej mapy geologicznej Polski w skali 1:50000, ark. Daleszyce [Explanations to the Detailed Geological Map of Poland 1:50000, Daleszyce sheet]. Warszawa, 77pp.

Filonowicz, P., 1980. Objaśnienia do Mapy geologicznej Polski w skali 1:200000, ark. Kielce [Explanations to the Geological Map of Poland 1: 200 000, Kielce sheet]. Warszawa, 143pp.

French, H.M., 1996. The Periglacial Environment. $2^{\text {nd }}$ Edition. Addison Wesley Longman, 341pp.

Gad, A. \& Juszczyk, A., 1986. Dokumentacja geologiczna złoża czwartorzędowych piasków budowlanych "Napęków" [Geological documentation of the Quaternary construction sands "Napęków”]. Przedsiębiorstwo Geologiczne, Kielce. 
Goździk, J., 1980. Zastosowanie morfometrii i graniformametrii do badan osadów w kopalni węgla brunatnego Bełchatów [The application morphometry and graniformametry to research deposits in Bełchatów brown coal mine]. Studia Regionalne 4(9), 101-114.

Goździk, J., 2001. Stratygrafia i paleogeografia osadów czwartorzędowych z środkowo-zachodniej części kopalni Bełchatów z wykorzystaniem morfoskopii ziarn kwarcowych. [Stratigraphy and palaeogeography of Quaternary sediments in central-western part of the mine Bełchatów with the use of quartz grains analysis]. [In:] E. Mycielska-Dowgiałło (Ed.): Eolizacja osadów jako wskaźnik stratygraficzny czwartorzędu [Aeolisation of sediments as an indicator of Quaternary stratigraphy]. Warszawa, 21-33 (in Polish).

Goździk, J., 2007. The vistulian aeolian succession in central Poland. Sedimentary Geology 193, 211-220.

Gradziński, R., Kostecka, A., Radomski, A. \& Unrug, R., 1986. Zarys sedymentologii [Outline of sedimentology]. Wyd. Geol., Warszawa, 628pp. (in Polish).

Harris, Ch., Murton, J. \& Davies, M.C.R., 2000. Soft-sediment deformation during thawing of ice-rich frozen soils: results of scaled centrifuge modeling experiments. Sedimentology 47, 687-700.

Hart, J.K., 2006. An investigation of subglacial processes at the microscale from Briksdalsbreen, Norway. Sedimentology 53, 125-146.

Hart, J.K. \& Boulton, G.S., 1991. The interrelation of glaciotectonic and glaciodepositional processes within the glacial environment. Quaternary Science Reviews 10, 335-350.

Hart, J.K. \& Roberts, D., 1994. Criteria to distinguish between glaciotectonic and glaciomarine sedimentation. I. Deformational styles and sedimentology. Sedimentary Geology 91, 191-213.

Hiemstra, J.F., 2001. Microscopic analyses of Quaternary glacigenic sediments of Marguerite Bay, Antarctic Peninsula. Arctic. Antarctict and Alpine Research 33, 258-265.

Hiemstra, J.F. \& van der Meer, J.J.M., 1997. Pore-water controlled grain fracturing as an indicator for subglacial shearing in tills. Journal of Glaciology 43, 446-454.

Hiemstra, J.F. \& Rijsdijk, K.F., 2003. Observing artificially induced strain; implications for subglacial deformation. Journal of Quaternary Science 18, 373-383.

Holliday, V.C. \& Rawling, III J.E., 2006. Soil-geomorphic relations of lamellae in eolian sand on the High Plains of Texas and New Mexico. Geoderma 131, 154-180.

Jahn A., 1951, Zjawiska krioturbacyjne współczesnej i plejstoceńskiej strefy peryglacjalnej [Cryoturbation phenomenon of contemporary and Pleistocene periglacial zones]. Acta Geologica Polonica 2, 159-290 (in Polish, with English summary).

Johnson, D.L., Johnson, D.N., Benn, D.W. \& Bettis, III, E.A., 2008. Deciphering complex soil/site formation in sands. Geomorphology 101, 484-496.

Kasse, C., Vandenberghe, J., Van Huissteden, J., Bohncke, S.J.P. \& Bos, J.A.A., 2003. Sensitivity of Weichselian fluvial systems to climate change (Nochten mine, eastern Germany). Quaternary Science Reviews 22, 2141-2156.
Kessler, T.C., Klint, K.E.S., Nilsson, B. \& Bjerg, P.L., 2012. Characterization of sand lenses embedded in tills. Quaternary Science Reviews 53, 55-71.

Kilfeather, A.A. \& van der Meer, J.J.M., 2008. Pore size, shape and connectivity in tills and their relationship to deformation processes. Quaternary Science Reviews 27, 250-266.

Konon, A., 2008. Regionalizacja tektoniczna Polski: Góry Świętokrzyskie i regiony przyległe (Tectonic subdivision of Poland: Holy Cross Mountains and adjacent areas). Przeglad Geologiczny 56, 921-926 (in Polish, with English summary).

Kosmowska-Sufczyńska, D., 1972. Z badań nad zasięgiem zlodowacenia środkowopolskiego w Górach Swiętokrzyskich (Pasmo Jeleniowskie-dolina Kamiennej) [The extent of the Middle Polish Glaciation in Holy Cross Mts (Southern Poland)]. Rocznik Polskiego Towarzystwa Geologicznego 42, 93-104 (in Polish, with English summary).

Kotański, Z., 1959. Przewodnik geologiczny po Górach Świętokrzyskich [Geological guide to the Holy Cross Mts]. Wyd. Geol., Warszawa, 204 pp. (in Polish).

Kowalski, B., 1988. Rozwój przełomowego odcinka doliny Lubrzanki przez główne pasmo Gór Świętokrzyskich w czwartorzędzie [The development of the sculpture of the water gape stretch of the Lubrzanka river through the main range of the Świętokrzyskie Mountains in the Quaternary period]. Przeglad Geograficzny 60, 635-655 (in Polish, with English summary).

Kowalski, B., Gromada, E. \& Swałdek, M., 1979. Granulometryczna i litologiczno-petrograficzna charakterystyka gliny zwałowej z Doliny Wilkowskiej w Górach Świętokrzyskich [Granulometric and litho-petrographic characteristics of boulder clay from the Wilkowska Valley in the Holy Cross Mountains]. Rocznik Polskiego Towarzystwa Geologicznego 49, 343-377 (in Polish, with English summary).

Krüger, J., 1984. Clasts with stoss-lee form in lodgement tills: a discussion. Journal of Glaciology 30, 241-243.

Krüger, J., Kjaer, K.H. \& Schomacker, A., 2010. DeadIce Environments: A Landsystems Model for a Debris-Charged, Stagnant Lowland Glacier Margin, Kötlujökull. Developments in Quaternary Sciences 13, 105-126.

Krumbein, W.C, 1941. Measurement and geological significance of shape and roundness of sedimentary particles. Journal of Sedimentary Petrology 11, 64-72.

Kubala-Kukuś, A., Ludwikowska-Kędzia, M., Banaś, D., Braziewicz, J., Majewska, U., Pajek, M. \& Wudarczyk-Moćko, J., 2013. Application of the X-ray fluorescence analysis and X-ray diffraction in geochemical studies of the Pleistocene tills from Holy Cross Mountains. Radiation Physics and Chemistry 93, 92-98.

Lachniet, M.S., Larson, G.J., Strasser, J.C., Lawson, D.E. \& Evenson, E.B., 1999. Microstructures of glacigenic sediment flow deposits, Matanuska Glacier, Alaska. [In:] D.M. Mickelson \& J.W. Attig (Eds): Glacial Processes Past and Present. Geological Society of America, Special Paper 337, 45-57.

Lachniet, M.S., Larson, G.J., Lawson, D.E., Evenson, E.B. \& Alley, R.B. 2001. Microstructures of sediment flow 
deposits and subglacial sediments: a comparison. Boreas 30, 254-262.

Lamparski, Z., 1970. Dynamika ruchu brzeżnej części lądolodu w czasie transgresji zlodowacenia środkowopolskiego na północno-wschodnie zbocza Gór Świętokrzyskich [The dynamics of ice movement of the marginal part of the ice sheet during the advance of the Middle Polish glaciation onto the north-eastern slopes of the Holy Cross Mts]. Acta Geologica Polonica, 20, 587-602 (in Polish, with English summary).

Larsen, N. K., Piotrowski, J. A. \& Christiansen, F., 2006: Microstructures and microshears as proxy for strain in subglacial diamicts: implications for basal till formation. Geology 34, 889-892.

Lindner, L., 1978. Rozwój paleogeomorfologiczny zachodniej części regionu świętokrzyskiego w plejstocenie [Palaeogeomorphologic evolution of the western part of the Holy Cross region in Pleistocene]. Rocznik Polskiego Towarzystwa Geologicznego 48, 479-508 (in Polish, with English summary).

Lindner, L., 1980. Zarys chronostratygrafii czwartorzędu regionu świętokrzyskiego [An outline of chronostratigraphy of the Quaternary in the Góry Świętokrzyskie Mts region]. Kwartalnik Geologiczny 24, 689-710 (in Polish, with English summary).

Lindner, L., 1984. Region świętokrzyski [The Holy Cross Region]. [In]: J.E. Mojski (Ed.) Budowa Geologiczna Polski, t. 1, Stratygrafia, cz. 3b, Kenozoik-czwartorzed [Holy Cross Mts Region. In: Geological structure of Poland, vol. 1, Stratigraphy, p. 3b, Cenozoic - Quaternary]. Wyd. Geol., Warszawa, 396 pp. (in Polish).

Lindner, L., 2004. Zarys stratygrafii plejstocenu regionu świętokrzyskiego w świetle nowych danych [Outline of Pleistocene stratigraphy of the Holy Cross Mountains area in light of new data]. Prace Instytutu Geografii Akademii Świętokrzyskiej w Kielcach 13, 7-31 (in Polish, with English summary).

Lindner, L. \& Ruszczyńska-Szenajch H., 1977. Zagadnienie genetycznego zróżnicowania glin zwałowych i osadów pokrewnych [The problem of genetic distinguishment of tills and glacial deposits]. Przeglad Geologiczny 8-9, 432-438 (in Polish, with English summary).

Lindner, L. \& Marks, L., 2012. O podziale klimatostratygraficznym kompleksu środkowopolskiego w plejstocenie Polski [Climatostratigraphic subdivision of the Pleistocene Middle Polish Complex in Poland]. Przeglad Geologiczny 60, 36-45 (in Polish, with English summary).

Liszkowski, J., 1976. W sprawie lodowcowego pochodzenia materiału trzeciorzędowego $\mathrm{z}$ centralnych rejonów Gór Świętokrzyskich [In the case of glacial origin of Tertiary material from the central areas of the Holy Cross Mountains]. Przeglad Geologiczny 24, 463-469.

Ludwikowska-Kędzia, M., 2000. Ewolucja środkowego odcinka doliny rzeki Belnianki w późnym glacjale i holocenie [Evolution of the middle segment of the Belnianka River valley in the Late Glacial and Holocene]. Dialog Press, Warsaw, 180 pp. (in Polish).
Ludwikowska-Kędzia, M., 2013. The assemblages of transparent heavy minerals in Quaternary sediments of the Kielce-Łagów Valley (Holy Cross Mountains, Poland). Geologos 19, 95-129.

Ludwikowska-Kędzia, M. \& Pawelec, H., 2011. Osady glacigeniczne w rejonie Mąchcocic Kapitulnych [Glacigenic sediments near Mąchocice Kapitulne (Holy Cross Mountains)]. [In:] M. Ludwikowska-Kędzia \& M. Wiatrak (Eds): Geologia i geomorfologia Regionu Świętokrzyskiego, 71-87 (in Polish, with English summary).

Ludwikowska-Kędzia, M., Pawelec, H. \& Adamiec, G., 2013. Deposits of Odranian Glaciation (=Saalian) in the Kielce-Łagów Valley (Holy Cross Mountains, Poland). International Field Symposium "Palaeolandscapes from Saalian to Weichselian", Lithuania, Vilnius, 68-69.

Łyczewska, J., 1971. Czwartorzęd regionu świętokrzyskiego. Stratygrafia kenozoiku Gór Świętokrzyskich i ich obrzeżenia [Quaternary of the Holy Cross Mountains Region. Cenozoic Stratigraphy of the Holy Cross Mountains and its margin]. Prace Instytutu Geologicznego 42, 5-86.

Łyczewska, J., 1972. Niektóre problemy czwartorzędu region świętokrzyskiego [Problems of Quaternary Investigations in the Holy Cross Mountains]. Rocznik Polskiego Towarzystwa Geologicznego 42, 81-92 (in Polish, with English summary).

Marks, L., 2011. Quaternary Glaciations in Poland. Developments in Quaternary Science 15, 299-303.

Menzies, J., 2000. Micromorphological analyses of microfabrics and microstructures, indicative of deformation processes, in glacial sediments. [In:] A.J. Maltman, B. Hubbard \& M.J. Hambrey (Eds): Deformation of Glacial Materials, Geological Society London, 245-258.

Menzies, J., 2012. Strain pathways, till internal architecture and microstructures - perspectives on a general kinematic model - a 'blueprint' for till development. Quaternary Science Reviews 50, 105-124.

Menzies, J. \& Maltman, A.J., 1992. Microstructures in diamictons evidence of subglacial bed conditions. Geomorphology 6, 27-40.

Menzies, J. \& Zaniewski, K., 2003. Microstructures within a modern debris flow deposit derived from Quaternary glacial diamicton - a comparative micromorphological study. Sedimentary Geology 157, 31-48.

Menzies, J. \& Brand, U., 2007. The internal sediment architecture of a drumlin, Port Byron, New York State, USA. Quaternary Science Reviews 26, 322-335.

Menzies, J., van der Meer, J.J.M. \& Rose, J., 2006. Till-as a glacial "tectomict", its internal architecture, and the development of a "typing" method for till differentiation. Geomorphology 75, 172-200.

Miall, A.D., 1977. A review of the braided-river depositional environment. Earth Science Reviews 13, 1-62.

Miall, A.D., 1978. Lithofacies types and vertical profile models in braided river deposits: A summary. [In:] A.D. Miall (Ed.): Fluvial Sedimentology. Canadian Society of Petroleum Geologists, Memoir 5, 597-604. 
Miall, A.D., 1980. Cyclicity and the facies model concept in geology. Bulletin of Canadian Petroleum Geology 28, 59-80.

Miall, A.D., 1985. Architectural-element analysis: new method of facies analysis applied to fluvial deposits. Earth-Science Reviews 22, 261-308.

Mycielska-Dowgiałło, E., 1978. Rozwój rzeźby fluwialnej północnej części Kotliny Sandomierskiej w świetle badań sedymentologicznych [Evolution of the fluvial relief in the northern part of Sandomierz Basin in the light of sedimentological studies]. Rozprawy Uniwersytetu Warszawskiego 120, 167 pp. (in Polish, with English summary).

Mycielska-Dowgiałło, E., 1995. Wybrane cechy teksturalne osadów i ich wartość interpretacyjna [Some textural features and interpretation opportunities]. [In:] E. Mycielska-Dowgiałło \& J. Rutkowski (Eds), Badania osadów czwartorzędowych. Wybrane metody i interpretacja wyników [Research into Quaternary deposits. Selected methods and interpretation of the results]. Warszawa, 29-105.

Mycielska-Dowgiałło, E., 1996. Analiza sedymentologiczna piaszczystych osadów eolicznych i jej znaczenie dla określenia długości trwania procesów pustynnienia [Sedimentological analysis of aeolian sand deposits and its importance for determining the duration of the processes of desertification]. Rocznik Świętokrzyski, B - Nauki Przyrodnicze 23, 109-116 (in Polish, with English summary).

Mycielska-Dowgiałło, E., 2001. Teksturalne cechy osadów wskazujące na stopień ich eolizacji i pozycję stratygraficzną [Textural characteristics of sediments indicating the degree of their aeolization and stratigraphic position]. [In:] E. Mycielska-Dowgiałło (Ed.), Eolizacja osadów jako wskaźnik stratygraficzny czwartorzedu [Aeolisation of sediments as an indicator of Quaternary stratigraphy]. Warszawa, 9-17 (in Polish).

Mycielska-Dowgiałło, E., 2007. Metody badań cech teksturalnych osadów klastycznych i wartość interpretacyjna wyników [Research methods for textural features of clastic deposits and the significance of interpretational results]. [In:] E. Mycielska-Dowgiałło \& J. Rutkowski (Eds): Badania cech teksturalnych osadów czwartorzędowych i wybrane metody oznaczania ich wieku. [Research into the textural features of Quaternary sediments and some dating methods]. Warsaw, 95-180 (in Polish).

Mycielska-Dowgiałło, E. \& Woronko, B., 1998. Analiza obtoczenia i zmatowienia powierzchni ziarn kwarcowych frakcji piaszczystej i jej wartość interpretacyjna [Rounding and frosting analysis of quartz grains of sand fraction, and its interpretative value]. Przeglad Geologiczny 46,1275-1281 (in Polish, with English summary).

Narloch, W., Piotrowski, J.A., Wysota, W., Larsen, N.K. \& Menzies J., 2012. The signature of strain magnitude in tills associated with the Vistula Ice Stream of the Scandinavian Ice Sheet, central Poland. Quaternary Science Reviews 57, 105-120.

Narloch, W., Wysota, W. \& Piotrowski, J.A., 2013. Sedimentological record of subglacial conditions and ice sheet dynamics of the Vistula Ice Stream (north-central Poland) during the Last Glaciation. Sedimentary Geology 293, 30-44.

Pawłowska, J., 1971. Petrografia skał turnejskich synkliny łagowskiej [The petrography of the Tournaisian rocks of the Łagów syncline]. Biuletyn Instytutu Geologicznego 195, 29-58 (in Polish, with English summary).

Pederson, S.A.S., 2005. Structural analysis of the Rubjerg Knude Glaciotectonic Complex, Vendsyssel, northern Denmark. Geological Survey of Denmark and Greenland Bulletin, 8, 192 pp.

Phillips, E., 2006. Micromorphology of a debris flow deposit: evidence of basal shearing, hydrofracturing, liquefaction and rotational deformation during emplacement. Quaternary Science Reviews 25, 720-738.

Phillips, E., Lee, J.R. \& Burke, H., 2008. Progressive proglacial to subglacial deformation and syntectonic sedimentation at the margins of the Mid-Pleistocene British Ice Sheet: evidence from north Norfolk, UK. Quaternary Science Reviews 27, 1848-1871.

Phillips, E. \& Lee, J.R. 2011. Description, measurement and analysis of glacitectonically deformed sequences. [In:] E. Phillips, J.R. Lee \& H.M. Evans (Eds): Glacitectonics - Field Guide. Quaternary Research Association, 5-31.

Piotrowski, J., Larsen, N.K. \& Junge, F.W., 2004a. Soft subglacial beds: a mosaic of deforming and stable spots. Quaternary Science Reviews 23, 993-1000.

Piotrowski, J.A., Larsen, N.K. \& Junge, F.W., 2004b. Reflections on soft subglacial beds as a mosaic of deforming and stable spots. Quaternary Science Reviews 18, 737-751.

Piotrowski, J.A., Larsen, N.K., Menzies, J. \& Wysota, W., 2006. Formation and subglacial till under transient bed conditions: deposition, deformation, and basal decoupling under Weichselian ice sheet lobe, central Poland. Sedimentology 53, 83-106.

Pisarska-Jamroży, M., 2006. Transitional deposits between end moraine and sandur plain in the Pomeranian glaciomarginal zone of NW Poland: a missing component of ice-contact sedimentary models. Boreas 35, 126-141.

Pisarska-Jamroży, M., 2007. Glacifluwialne facje strumieni przeciążonych zawiesin na przykładzie plejstoceńskich osadów wschodniej Jutlandii i Pomorza Zachodniego [Glaciofluvial facies of hyperconcentrated flow (the Pleistocene of Denmark and Western Pomerania)]. Przeglad Geologiczny 55, 503-510 (in Polish, with English summary).

Prusinkiewicz, Z., Bednarek, R., Kosko, A. \& Szmyt, M., 1998. Paleopedological studies of the age and properties of illuvial bands at an archaeological site. Quaternary International 51/52, 195-201.

Racinowski, R., 2008. Znaczenie analizy minerałów ciężkich w badaniach osadów czwartorzędowych Polski [Significance of Heavy Minerals Analysis in the Studies of the Quaternary Deposits in Poland]. Annales Universitatis Mariae Curie-Skłodowska, sec. B, 63, 7-44 (in Polish, with English summary).

Racinowski, R., 2010. Główne przeźroczyste minerały ciężkie w osadach czwartorzędowych Polski [Main 
transparent heavy minerals in Quaternary deposits of Poland]. Biuletyn Państwowego Instytutu Geologicznego 438, 99-106 (in Polish, with English summary).

Radłowska, C. \& Mycielska-Dowgiałło, E., 1974. Deglaciation in the Świętokrzyskie Mts. Geographia Polonica $28,19-48$.

Rawling, J.E., 2000. A review of lamellae. Geomorphology $35,1-9$.

Roberts, D. H. \& Hart, J. K., 2005. The deforming bed characteristics of a stratified till assemblage in North East Anglia, UK: investigating controls on sediment rheology and strain signatures. Quaternary Science Reviews 24, 123-140.

Różycki, S.Z., 1972a. Problemy czwartorzędu w Górach Świętokrzyskich [Problems of Quaternary in the Holy Cross Mountains]. Rocznik Polskiego Towarzystwa Geologicznego 42, 67-79 (in Polish, with English summary).

Różycki, S.Z., 1972b. Plejstocen Polski środkowej [Pleistocene of Central Poland]. PWN, Warszawa (in Polish).

Ruszczyńska-Szenajch, H., Trzciński, J. \& Jarosińska, U., 2003. Lodgement till deposition and deformation investigated by macroscopic observation, thin-section analysis and electron microscope study at site Dębe, central Poland. Boreas, 32, 399-415.

Sołtysik, R., 1998. Peryglacjalna zwietrzelina gliniasta Doliny Chęcińskiej w Górach Świętokrzyskich [Periglacial weathered covers in the Chęcińska Valley in the Holy Cross Mts]. Przeglad Geologiczny 46, 456-458 (in Polish, with English summary).

Sołtysik, R., 2002. Geneza i wiek osadów gliniastych w Górach Świetokrzyskich [Genesis and age of surface clays in the Holy Cross Mts]. Prace Instytutu Geografii Akademii Świętokrzyskiej w Kielcach 8, 139-150 (in Polish, with English summary).

Turkowska, K., 2006: Geomorfologia regionu tódzkiego [Geomorphology of Łódź Region]. Uniwersytet Łódzki Press, 238 pp. (in Polish).

Van der Meer, J.J.M., 1993. Microscopic evidence of subglacial deformation. Quaternary Science Reviews 12, 553-587.

Van der Meer, J.J.M., 1997. Particle and aggregate mobility in till: Microscopic evidence of subglacial processes. Quaternary Science Reviews 16, 827-831.

Van der Meer, J.J.M., Menzies, J. \& Rose, J., 2003. Subglacial till: the deforming glacier bed. Quaternary Science Reviews 22, 1659-1685.

Walczowski, A., 1962. Utwory czwartorzędowe w okolicach Rakowa i Łagowa [Quaternary deposits near Raków and Łagów]. Kwartalnik Geologiczny 6, 469-482.

Walczowski, A., 1968. Objaśnienia do Szczegótowej mapy geologicznej Polski 1 :50 000, ark. Łagów [Explanations to Detailed Geological Map of Poland 1: 50 000, sheet Łagów]. Wyd. Geol., Warszawa, 82 pp.

Waller, R., Phillips, E., Murton, J., Lee, J. \& Whiteman, C., 2011. Sand intraclasts as evidence of subglacial deformation of Middle Pleistocene permafrost, North Norfolk, UK. Quaternary Science Reviews 30, 3481-3500.

Woronko, B., 2001. Znaczenie analizy obtoczenia i zmatowienia powierzchni ziarn kwarcowych frakcji piasz- czystej w interpretacji genetycznej osadów czwartorzędowych [The importance of analyzing roundness and matt surfaces of quartz grains of sand fraction in the genetic interpretation of Quaternary sediments]. [In:] E. Mycielska-Dowgiałło (Ed.), Eolizacja osadów jako wskaźnik stratygraficzny czwartorzędu [Aeolisation of sediments as an indicator of Quaternary stratigraphy]. Uniwersytet Warszawski, Warszawa, 33-38 (in Polish).

Woronko, B., 2012. Zapis procesów eolicznych w osadach piaszczystych plejstocenu na wybranych obszarach polski środkowej i pótnocno-wschodniej [Record of aeolian processes in the Pleistocene sandy deposits in the selected areas of central Poland]. Warsaw University Press, 130 pp. (in Polish, with English summary).

Wyszomirski, P. \& Galos, J., 2009. Polish clayey raw materials for the production of ceramic tiles. Clay Minerals 44, 493-505.

Wyszomirski, P., Galos, J., Szajn, S. \& Piskorz S., 2006. Gościniec - nowe złoże surowca ilastego dla przemysłu ceramicznego [Gościniec - new clay deposits for ceramic industry]. Ceramika 96, 1-10 (in Polish, with English summary).

Wyszomirski, P., Muszyński, M. \& Zawrzykraj, W., 2010. Czerwone iły ze Szkucina (woj. świętokrzyskie) i ich przydatność przemysłowa [Red clays from Szkucin (świętokrzyskie voivodeship) and their industrial application]. Gospodarka surowcami mineralnymi 26, 5-20 (in Polish, with English summary).

Zieliński, T., 1993. Sandry Polski północno-wschodniejosady i warunki sedymentacji [Outwash plains of NE Poland - sediments and depositional processes]. Prace Naukowe Uniwersytetu Ślaskiego 1398, 96 pp. (in Polish, with English summary).

Zieliński, T., 1998. Litofacjalna identyfikacja osadów rzecznych [Lithofacial identification of alluvial sediments]. [In:] E. Mycielska-Dowgiałło (Ed.) Struktury sedymentacyjne $i$ postsedymentacyjne w osadach czwartorzedowych [Sedimentological and postsedimentological structures in Quaternary sediments and their value for interpretation]. Warsaw University Press, 193-257 (in Polish, with English summary).

Zieliński, T., 2014. Sedymentologia. Osady rzek i jezior [Sedimentology. Sediments of rivers and lakes]. Wyd. Nauk. UAM, Poznań, 594 pp. (in Polish).

Zieliński, T. \& Pisarska-Jamroży, M., 2012. Jakie cechy litologiczne warto kodować, a jakie nie? [Which features of deposits should be included in code and which not?]. Przeglad Geologiczny 60, 387-397 (in Polish, with English summary).

Znosko, J., 1962. W sprawie nowego nazewnictwa jednostek tektonicznych Gór Świętokrzyskich [New names of tectonic units of the Holy Cross Mountains]. Przeglad Geologiczny 9, 455-456 (in Polish).

Manuscript received: 10 July 2015 Revision accepted: 25 September 2015 